\title{
OPEN The variability of soils and vegetation of hydrothermal fields in the Valley of Geysers at Kamchatka Peninsula
}

\author{
I. N. Semenkov ${ }^{1 凶}$, G. V. Klink ${ }^{2}$, M. P. Lebedeva ${ }^{3}$, V. V. Krupskaya ${ }^{1,4}$, M. S. Chernov ${ }^{1}$, \\ O. V. Dorzhieva ${ }^{4}$, M. T. Kazinskiy ${ }^{1}$, V. N. Sokolov ${ }^{1}$ \& A. V. Zavadskaya ${ }^{5}$
}

The picturesque and high conservation value thermal landscapes of the Valley of Geysers feature endothermal (heated by endogenous fluids) soils which support endangered and unique species. However, such soils have not been distinguished as a separate taxon within most classification systems. In this study, we described the soil morphology at macro-, meso- and micro-scales, chemistry, mineralogy and vegetation of these landscapes as they are affected by the steam-heated acid-sulfate waters. The studied catenary sequence from exothermal (non-heated) to endothermal soils was characterized by decreasing contents of soil organic carbon, sand fraction, essential nutrients (Ca, K, Mg, Mn and $\mathrm{Si}$ ), increasing soil acidity, amounts of fine particle-size fractions and contents of trace elements ( $\mathrm{Al}, \mathrm{As}, \mathrm{Co}, \mathrm{Cr}, \mathrm{Cu}, \mathrm{Fe}, \mathrm{Pb}, \mathrm{Ti}$ and $\mathrm{V}$ ) as well as the development of sodium-sulfate salinity, kaolinization and ferrugination. In phytocenoses supported by endothermal soils, species of order Rosales and Asparagales were overrepresented among obligate and facultative thermophytes respectively, and species of order Poales were underrepresented among facultative thermophytes in relation to the flora of the Valley of Geysers. Phytocenoses on the non-heated Andosols were enriched in Polypodiopsida species. The results of our comparative analysis of the thermally-induced variability in the soils and vegetation contribute to the general understanding of mineralogical, bio-abiotic and biological systems affected by steam-heated acid-sulfate waters. We hope that our findings will provide a basis for future transdisciplinary studies of the influence of steam-heated waters of a hot spring on the thermal landscapes.

The picturesque thermal landscapes of the Valley of Geysers attract 1000-4100 tourists annually and are part of the UNESCO World Natural Heritage Site "Volcanoes of Kamchatka", which is one of 20 world natural heritage sites to meet all the qualifying criteria ${ }^{1,2}$. Areas, where hot fluids are discharged from the ground, can be used for obtaining renewable or 'green' energy. Such territories can also serve as natural laboratories to study the effects of increased $\mathrm{CO}_{2}$ concentrations in the soil atmosphere ${ }^{3}$ and climate warming ${ }^{4}$. Specific endothermal soils ${ }^{5}$ provide habitats for endangered, unique and protected plant species ${ }^{1,4,6-9}$ and microorganisms ${ }^{10-14}$. In Kamchatka's thermal landscapes (where the soils have summer temperatures of more than $30{ }^{\circ} \mathrm{C}$ at a $50-\mathrm{cm}$ $\operatorname{depth}^{8}$ ), the composition of vegetation and soil microbiota depends on changes in soil acidity, $\mathrm{H}_{2} \mathrm{~S}$ concentration, temperature, salinity and concentrations of toxic compounds $s^{4,6,7}$. However, there are still many unresolved questions about the relationship between the plants and soils within steam hydrotherm areas and around hot springs. Endothermal soils are not distinguished as a separate taxon within most classification systems ${ }^{15}$ and their mineralogical and micromorphological characteristics ${ }^{16-18}$ as well as their associated plant communities ${ }^{1,4,8}$ have been insufficiently studied.

Unlike endothermal soils that experience the influence of steam-heated chloride and hydrocarbonate waters ${ }^{19-22}$, endothermal soils that are affected by acid-sulfate waters differ considerably from non-heated soils $s^{1,5,18,23-25}$. Their topsoils are depleted in $\mathrm{Ca}, \mathrm{Mg}, \mathrm{Na}, \mathrm{K}$ and are intensively ferruginized up to the formation

${ }^{1}$ Lomonosov Moscow State University, Moscow, Russia. ${ }^{2}$ Institute for Information Transmission Problems (Kharkevich Institute) of the Russian Academy of Sciences, Moscow, Russia. ${ }^{3}$ V.V. Dokuchaev Soil Science Institute, Moscow, Russia. ${ }^{4}$ Institute of Geology of Ore Deposits, Petrography, Mineralogy and Geochemistry of the Russian Academy of Sciences (IGEM RAS), Moscow, Russia. ${ }^{5}$ Kronotsky Federal Nature Biosphere Reserve, Elizovo, Russia. ${ }^{\square}$ email: semenkov@geogr.msu.ru 
of large ferruginous nodules enriched in $\mathrm{Al}, \mathrm{Fe}$ and $\mathrm{Ti}^{18,23,26}$. In their subsoils, a specific clayey variegated horizon is formed ${ }^{18,23,24}$ - a probable analogue of the well-studied deep hydrothermal clays ${ }^{27-29}$ forming under higher pressure and temperature.

The aim of the present study is to close the transdisciplinary gap between pedology and botany within the zone of influence of steam-heated acid-sulfate waters of a hydrothermal field in the Valley of Geysers. We assume that the intensity of the effect of endogenous fluids on the soil matrix changes depends on the temperature, which affects the morphological and chemical properties and mineralogical composition of soils and the plant species composition.

\section{Results and discussion}

The catenary sequence of soils. The catena of Andosols down a slope near a hot spring in the Valley of Geysers was subdivided into four thermal zones (Fig. 1a-e), which are described below.

Zone I. Non-heated Eutrosilic Silandic Andosols (Arenic, Cutanic) under Kamchatka's tall herb communities and fragmented Erman's birch woods. Non-heated Andosols with temperatures of $<25{ }^{\circ} \mathrm{C}$ at the depth of $15 \mathrm{~cm}$ were stratified (Table S1, Figure S1). In the sandy A-horizon (Fig. 1f), the micromass of soil fabric was wellstructured due to highly active micro- and mesofauna and contained numerous brownish coprolites typical for Andosols ${ }^{30,31}$. Both modern and buried A-horizons showed a granular-angular blocky structure and contained plant remains, oval-shaped dense biogenic aggregates and small concentrations of brown collomorphic Al-Fehumus material (Fig. 2a).

The Bt-horizon had a massive macrostructure (Table S2) and a pellicular grain microstructure consisting of microaggregates of loose consistency (containing silt-sized grains of plagioclases, weathered volcanic ash and heavy minerals ${ }^{32}$ ) covered with collomorphic Fe-humus coatings (Fig. 2b). The soil horizon buried under volcanic ash contained many sand-sized opaque and optically isotropic minerals (opal/cristobalite, volcanic glass). The coagulation of finely-dispersed ferruginous and collomorphic substances resulted from 'intra-soil metamorphism ${ }^{33}$ or 'andozolization' ${ }^{34}$ - the main pedogenic process in non-heated Andosols. Neither illuvial clay coatings nor unaltered volcanogenic sand-silt material were present.

In the topsoil $(0-10 \mathrm{~cm})$, the particle-size distribution (Table S3) was characterized by the prevalence of $\mathrm{PM}_{>50}$ with very small amounts of $\mathrm{PM}_{5-50}(<10 \%)$ and $\mathrm{PM}_{<1}(0.5 \%)$, while the subsoil (Table S4) had higher contents of $\mathrm{PM}_{<5}$ and $\mathrm{PM}_{10-50}$ (abbreviations of particle-size fractions are explained in Methods), lower contents of $\mathrm{PM}_{500-1000}$ and similar contents of $\mathrm{PM}_{50-250}$ (Table S5). With depth, $\mathrm{pH}$ increased from 5.7 to 6.8 and redox potential (Eh) from -35 to $+497 \mathrm{mV}$, while the value of electrical conductivity (EC) and the content of soil organic carbon (SOC) decreased by 2 and 30 times, respectively. A low EC value reflected an absence of salinization in nonheated Andosols. A high SOC content and a weakly acid reaction in the topsoil were favorable for the formation of Al-organic complexes and unfavorable for allophane formation ${ }^{33,35}$.

In the Zone I soils, feldspars (albite-anorthite) were the main primary minerals constituents with cristobalite and rarer zeolites presented in smaller amounts. The non-heated Andosols also contained clay minerals, predominantly swelling minerals_-dioctahedral smectites (probably montmorillonites). Smectites were unambiguously diagnosed by the X-ray diffraction patterns obtained from both powder and oriented air-dried and saturated with ethylene glycol specimens (Fig. 3a,e).

The upper $2 \mathrm{~m}$-thick layer of non-heated Andosols had the mineralogical composition typical for this soil type $^{27,36}$ and parent materials in the Valley of Geysers ${ }^{32}$, with predominant feldspars and smectite, frequent kaolinite, zeolites and occasional quartz, anatase, pyrite and goethite (Table S6). According to SEM and XRD data, the mineralogical and elemental composition changed insignificantly with depth, except for the appearance of newly formed opal and rare fragments of etched volcanic glass at a depth of more than $15 \mathrm{~cm}$ (Fig. 2i).

Zone II. Slightly heated Eutrosilic Aluandic Andosols (Cutanic, Loamic, Natric) under tall herb communities at the periphery of the steam hydrotherm. Slightly heated Andosols had temperatures of $25-40^{\circ} \mathrm{C}$ at a depth of $15 \mathrm{~cm}$ (Table 1). Their A-horizons (Fig. 1g) was better structured as compared to that of non-heated Andosols, which was due to higher contents of collomorphic Fe-organic material and clays (Table S7). Excrements of soil microbiota occurred within some microzones of the topsoil. Dense silt-clay microaggregates contained inclusions of volcanogenic rock fragments, clay minerals and ash and had a random packing, according to SEM data.

The hydrothermally-induced alteration of slightly heated Andosols caused considerable changes in soil fabric (Fig. 2c,d). In the Btn-horizon, the number and distinctness of clayey layers of different colors consisting of a brown collomorphic organomineral material and a finely-dispersed material increased in the direction towards the hydrothermal field. The number of clay coatings within intrapedal pores increased with depth. Such coatings were probably formed due to alkalization and release of $\mathrm{Na}$ during weathering of primary minerals (with exchangeable $\mathrm{Na}$ content of $12.9(+) \mu \mathrm{mol} / \mathrm{kg}$ in the Btn-horizon and only $0.3-0.8(+) \mu \mathrm{mol} / \mathrm{kg}$ in upper horizons, Table S5). Such a process is typical for soils of the margins of thermal fields in the ultra humid environments of Kamchatka ${ }^{18}$.

The particle-size distribution was characterized by the predominance of $\mathrm{PM}_{>10}$. Compared to the non-heated Andosols, the slightly heated Andosols of zone II had a higher content of fine fractions $\left(\mathrm{PM}_{<10}\right)$ and a lower content of $\mathrm{PM}_{250-500}$ (Tables S8, S9). The content of $\mathrm{PM}_{<5}$ increased with depth, with insignificant differences in the contents of coarser fractions. Properties ( $\mathrm{pH}, \mathrm{SOC}$ and EC) of Andosols from both zones showed similar absolute values and similar vertical distribution.

Slightly heated Andosols had higher contents of Si, K and Sr, lower contents of Ti, V, Fe, Co and Ca and similar contents of $\mathrm{Cr}, \mathrm{Ni}, \mathrm{Cu}, \mathrm{Zn}, \mathrm{As}, \mathrm{Pb}, \mathrm{Al}, \mathrm{P}$ and $\mathrm{Mg}$ as compared to those of Zone I. Most elements showed uniform vertical distribution patterns, with the exception of $\mathrm{P}$, which showed increased values in the topsoil (Fig. 4a). 

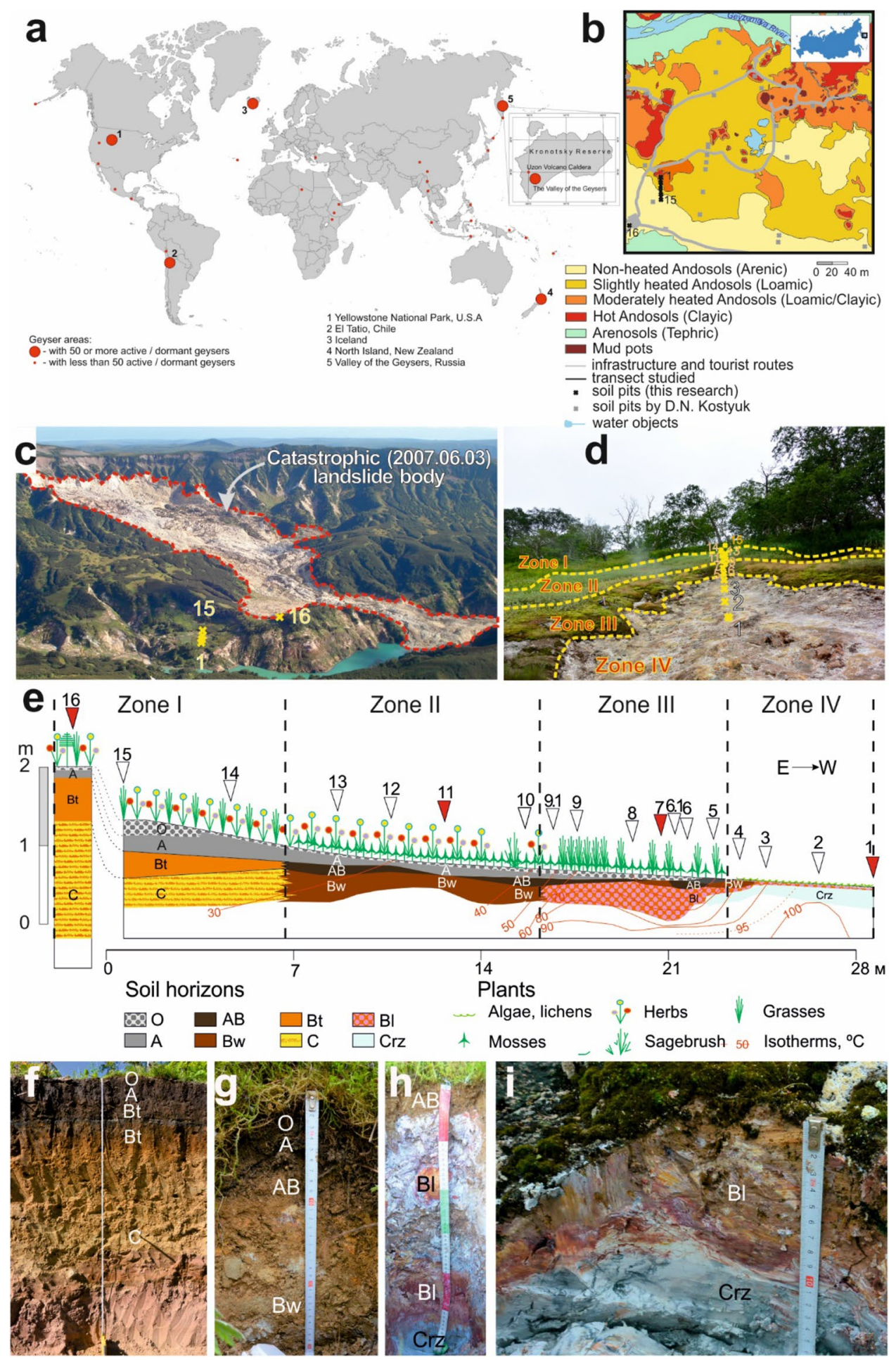

Figure 1. Location of study area (a-c), soil pits along the catena $(\mathbf{d}, \mathbf{e})$ and photos of soil pits $(\mathbf{f}-\mathbf{i})$. (a b) Study area location. Soil map is from ${ }^{133}$ (open access) with additions and corrections by I.N. Semenkov based on the map of soil temperature at a depth of $15 \mathrm{~cm}$ in the Valley of Geysers ${ }^{131}$ and the soil names from ${ }^{44}$ using CorelDraw X7 software (https://www.coreldraw.com/). (c) Top view of the left side of the Geysernaya River with the body of a catastrophic landslide, a visitor center (in the left lower part) and the location of the transect studied (1-15). (d) The location of transect studied. (e) A schematic profile of the catena studied with numbered soil pits. The main soil pits selected for comprehensive analyses (see section 'Soil analyses') are in red. (f) Non-heated Eutrosilic Silandic Andosols (Arenic, Cutanic) on pyroclastic material (pit no 16, Zone I), within levelled parts of the interfluve, under tall-herb meadow communities with local patches of Erman's birch woods. (g) Slightly heated Eutrosilic Aluandic Andosols (Cutanic, Loamic, Natric) in the upper part of the catena, on hydrothermally altered sandy-loamy pyroclastic material (pit no 12, Zone II), on slightly heated slopes, under tall-herb meadows. (h) Moderately heated Eutrosilic Gleyic Aluandic Andosols (Loamic, Reductic, Protosalic, Hyperthionic) in the middle part of the catena, on hydrothermally altered clayey pyroclastic material (pit no 9.1, Zone III), under different moss and 'microzonal' communities. (i) Hot Gleyic Aluandic Andosols (Clayic, Reductic, Salic, Hyperthionic) in the lower part of the catena, on hydrothermal clays (pit no 4, Zone IV), on most heated bare slopes. 
Zone I. Non-heated Andosols (pit 16)
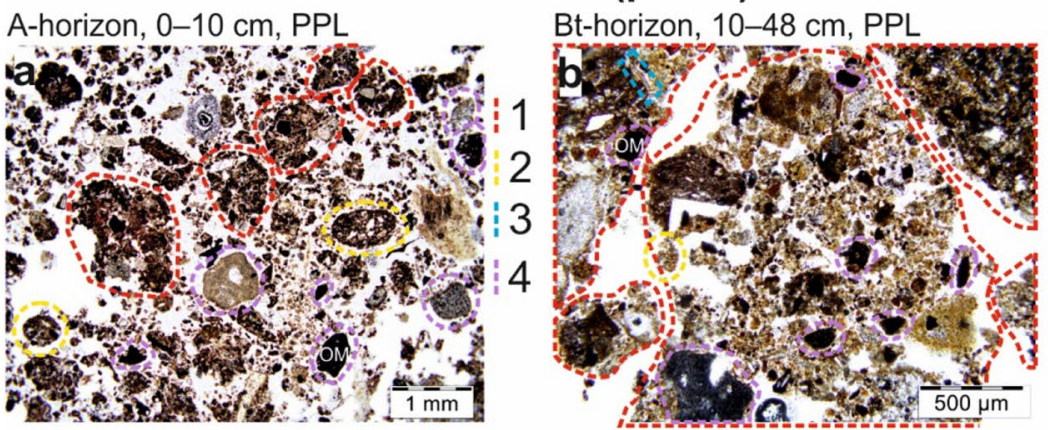

Zone II. Slightly heated Andosols (pit 11):
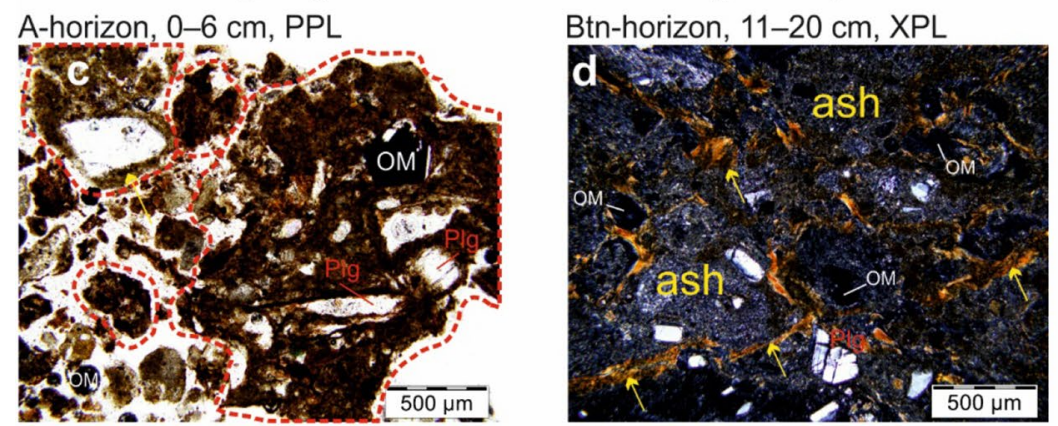

Zone III. Moderately heated Andosols (pit 7)

A-horizon, 0-4 cm, XPL

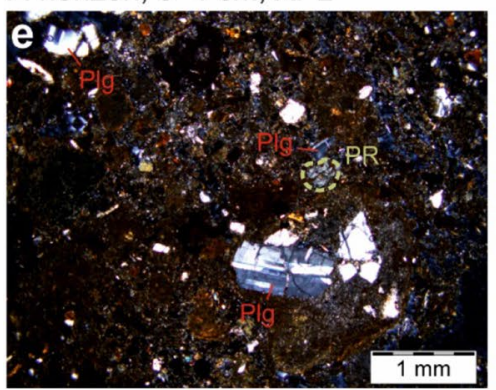

B-horizon, 4-7 cm, RL

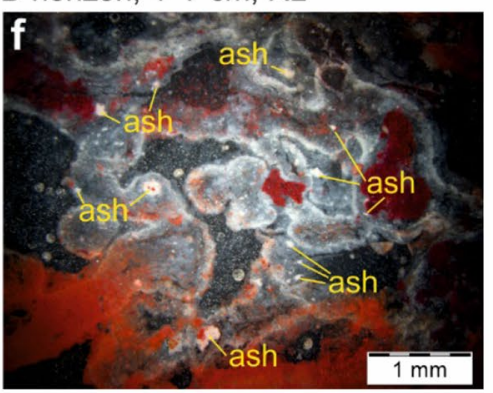

\section{Zone IV. Hot Andosols (pit 1)}

Az- and Bilz-horizons, $0-3 \mathrm{~cm}$, PPL

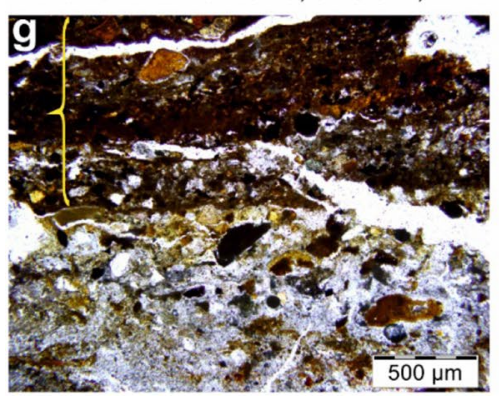

Bilz-horizons, 3-7 cm, RL

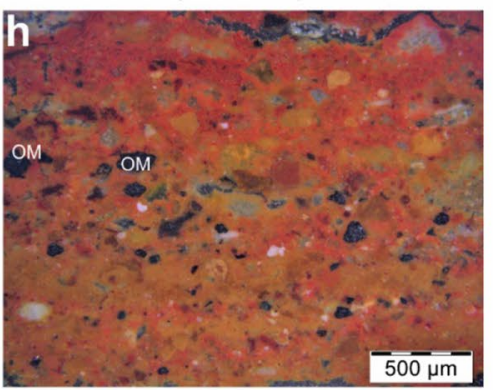

A-horizon

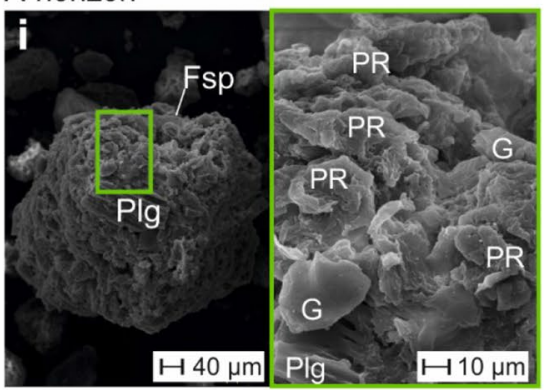

Btn-horizon

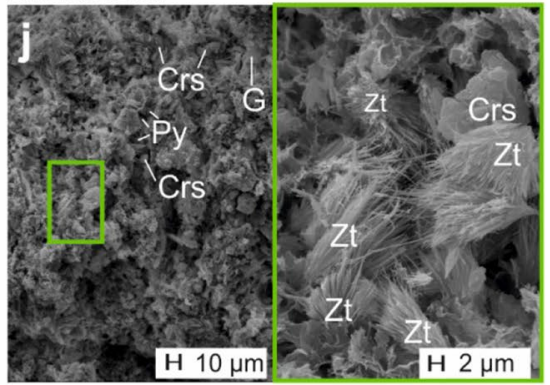

B-horizon

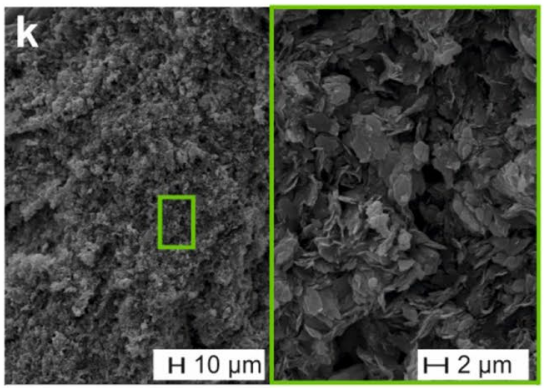

Az- and Bilz-horizons

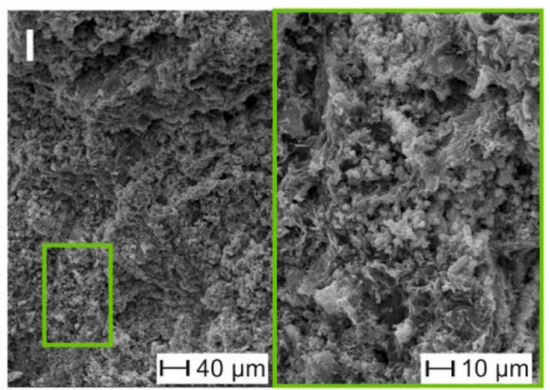


4Figure 2. Soil Fabric Of Andosols In The Valley of Geysers. Two left rows-optical microscopy images (plane polarized light-PPL; cross polarized light-XPL; reflected light-RL; photos by M.P. Lebedeva). Right row (photos by M.S. Chernov): i-l-SEM images at two magnifications: on the left-a general view of a microaggregate, on the right-a detailed image of the surface: (a) Loose, porous, microaggregated material with fragments of deeply altered rocks and minerals, brown microaggregates (peds-1) and coprolites of soil micro- and mesofauna (2), fragments of semidecayed plant remains (3). (b) Inclusions of deeply altered rocks and minerals (4) within a subangular blocky microaggregates (1) with Fe-humus-clay microconcentrations and small coprolites of mesofauna (2). (c) microaggregates (1) of different sizes consisting of a brown collomorphic organomineral material and a finely-dispersed material that binds fragments of plagioclases (Plg), ore minerals $(\mathrm{OM})$, with coatings of a collomorphic material (arrow). (d) Light-colored particles of argillized ash, with layered brownish yellow Fe-clay coatings (arrows) within intrapedal pores, singular small cracked grains of plagioclases (Plg) and ore minerals. (e) Granular, highly porous, brown material consisting of deeply altered fragments of volcanogenic minerals, assimilation of cracked sand-sized grains of plagioclases (Plg) and silt-sized grains of pyroxenes (PR). (f) A highly porous zone with rounded argillized ash particles with dark coatings and zones of iron hydroxide concentrations. (g) The uppermost part of a biogenic crust with microlayers of brown collomorphic material (brace) and yellow-white fine-crystalline material with charred particles as well as silty-collomorphic material with inclusions of silt-sized grains. (h) A red-colored zone with an intense intrusive impregnation by collomorphic Fe, with yellow altered argillized minerals and abundant charred particles and fine-silt-sized ore minerals (OM). (i) Sand- and silt-sized organomineral microaggregates consisting of volcanic glass (G) fragments (volcanic ash or tephra particles), crystals of plagioclases (Plg) and potassium feldspars (Fsp), microaggregates of clay particles and organic matter, with traces of activity of soil microorganisms and plant remains. (j) A non-oriented mass of densely packed silt-clay microaggregates consisting of kaolinite, smectite, mixed-layered clay minerals and fragments of primary volcanic minerals such as volcanic glass with intrapedal pores fully filled by newly formed (hydrothermal) minerals including pyrite, cristobalite and, presumably, zeolite (acicular crystals of zeolite minerals). (k) Kaolinite microaggregates with 'domain-like' microstructure in a non-oriented clay matrix. (l) A dense groundmass consisting of kaolinite and kaolinitesmectite mixed layered minerals microaggregates.

The topsoil of zone II differed from that of zone I in the predominance of smectite, noticeable amounts ( $>10 \%$ ) of feldspars and quartz (Table 2$)$, lower amounts $(<5 \%)$ of kaolinite, pyrite and cristobalite and the absence of considerable vertical differentiation (Table S8, Fig. 3b). Based on SEM data, newly formed hydrothermal pyrite and cristobalite also occurred (up to 5\%) and occasionally large intrapedal pores filled with acicular mordenite (>10\%) (Fig. 2j).

Zone III. Moderately heated Eutrosilic Gleyic Aluandic Andosols (Loamic, Reductic, Protosalic, Hyperthionic) under different moss and microzonal communities. Moderately heated Andosols with temperatures of $40-80{ }^{\circ} \mathrm{C}$ at a depth of $15 \mathrm{~cm}$ (Figure S2) were characterized by the formation of a surface crust (brown or cream colored, humified, with a fine subangular blocky-crumbly structure; Table S2) or, at the margin of this zone, an A-horizon with a structure from fine angular blocky to coarse subangular blocky and inclusions of ferruginized plant remains (Fig. 2h). Fragments of volcanic rocks were also considerably ferruginized, which indicated an intensive inflow of fluids saturated with mobile Fe. The topsoil $(0-4 \mathrm{~cm})$ of zone III as compared to that of zone I had similar porosity, lower content of organic debris and collomorphic organomineral microaggregates and higher degrees of ferrugination of groundmass which isometric fragments consist of cracked sand-sized grains of plagioclases, weathered volcanic ash and heavy minerals. The SEM analysis showed that the topsoil had inherited the matrix microstructure similar to that in soils of zone II with apparent pseudomorphs over primary structural elements and a total replacement of initial rocks as a result of hydrothermal alteration as previously reported for thermally altered tuffites in Kamchatka ${ }^{28}$. The non-oriented clay matrix contained silty peds (Fig. 2k). In the subsoil, volcanogenic source rocks were strongly argillized.

Below the root zone, a relatively homogenous brown Bw-horizon of an altered volcanogenic material with a subangular blocky-angular blocky structure containing less than $20 \%$ of $\mathrm{PM}_{>10}$ was most often present. The $\mathrm{Bw}$-horizon was underlain by a clayey B1-horizon with an angular blocky-prismatic or massive structure and various colors (alternating white, violet, ochric, red, brown and lilac stripes and mottles). On a micro scale, this material showed mostly dark gray hues in plain polarized light and a red, fluidal texture in reflected light (Fig. 2f), indicating the presence of intrusive ferruginous pedofeatures and a high content of anatase and alunite-jarosite. Similar brightly colored B1-horizons have been detected in endothermal soils of Iceland ${ }^{5}$, Kamchatka ${ }^{18,24}$ and California ${ }^{37}$. Therefore, it could be suggested that such horizons, which form under the influence of steam-heated acid sulfate water, occurred worldwide.

The Bl-horizon was underlain by a bleached white (whitish gray background matrix with cream and light blue mottles) clayey parent material (Fig. 1h). Some angular blocky and prismatic peds had red films on their surface and sides.

Compared to the non-heated Andosols, the moderately heated Andosols had higher amounts of fine particlesize fractions and lower content of $\mathrm{PM}_{250-500}$. The topsoil of zone III was dominated by $\mathrm{PM}_{>10}$ and the subsoil $\left(>10 \mathrm{~cm}\right.$ ) by $\mathrm{PM}_{<5}$ (Tables S8, S9). In the subsoil, $\mathrm{PM}_{250-1000}$ were absent, the content of $\mathrm{PM}_{10-50}$ was lower and the content of $\mathrm{PM}_{<5}$ higher than in the topsoil, while the content of $\mathrm{PM}_{5-10}$ and $\mathrm{PM}_{50-250}$ was similar.

In comparison to non-heated Andosols, moderately heated Andosols had higher Eh and EC and lower $\mathrm{pH}$ and SOC values due to the biogenic oxidation of sulfides with the production of sulfuric acid, which was confirmed by the presence of colonies of iron-oxidizing bacteria (Fig. 2f). SOC, pH, EC and Eh changed insignificantly with depth. 


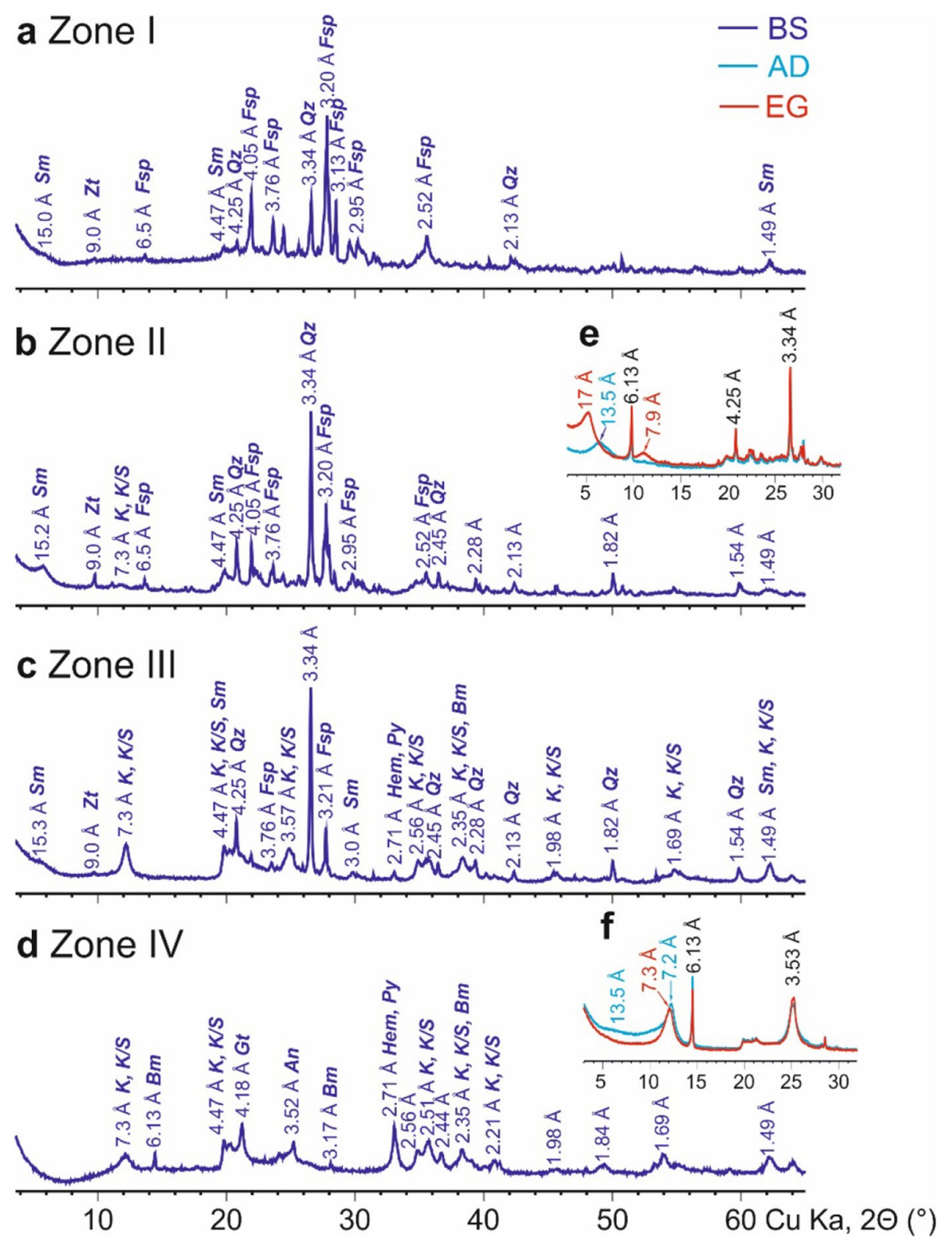

Figure 3. X-Ray diffraction patterns: (a-d) Bulk samples (BS) of Andosols from zones I (a), II (b), III (c), IV (d). (e, f) Fragments of XRD patterns from oriented $\leq 1 \mu \mathrm{m}$ samples in air-draied (AD) and ethylene-glycole solvated (EG) states for Andosols from zones II (e) and IV (f). Crystal lattice planes in Angstroms. The main reflections represent the following minerals: $S m$-smectite, $Z t$-zeolites, $K$-kaolinite, $K / S$-kaolinite-smectite mixed layered minerals, Bm-boehmite, Gt—goethite, Qz-quartz, Fs-feldspars, Hem-hematite, Py-pyrite.

The elemental composition of moderately heated Andosols differed from that of non-heated Andosols by a higher content of $\mathrm{Fe}, \mathrm{As}, \mathrm{Pb}$ and $\mathrm{Al}$ and a lower content of $\mathrm{Mn}, \mathrm{Ca}, \mathrm{K}, \mathrm{Mg}$ and $\mathrm{Sr}$, with similar content levels of V, Cr, Co, Ni, Cu, Zn, Si and P (Tables S8, S10). The topsoil of zone III had higher contents of Ca, K, Mg, Mn and $\mathrm{Si}$ and the subsoil was enriched in $\mathrm{Al}, \mathrm{As}, \mathrm{Cu}, \mathrm{Fe}, \mathrm{Ni}, \mathrm{Pb}, \mathrm{Ti}, \mathrm{V}$ and $\mathrm{Zn}$. The content of $\mathrm{P}, \mathrm{Sr}, \mathrm{V}, \mathrm{Cr}, \mathrm{Co}$ and Ca varied insignificantly with depth.

Compared to non-heated Andosols, moderately heated Andosols had a higher content of kaolinite (the predominant phase in matrix and peds) and anatase, a lower content of smectite, potassium feldspars and plagioclases and a similar content of pyrite, zeolites, quartz, cristobalite, hematite and goethite (Table S8, Fig. 4b) which coincides with data ${ }^{38}$ on the disappearance of smectite in hydrothermal altered rocks with a temperature exceeding $85-95^{\circ} \mathrm{C}$ at the Wairakei geothermal field, New Zealand. The topsoil was enriched in potassium feldspars and albite and impoverished in zeolite, anatase, quartz and cristobalite (SEM data showed that the last three minerals occurred within large intrapedal pores inherited from soils), with similar amounts of kaolinite, smectite and pyrite.

Judging from the XRD full patterns of kaolinite, it had a disordered structure (Fig. $3 \mathrm{~d}-\mathrm{f}$ ). It should be mentioned that the calculation of different indices (Hinckley, AGFI) using several peaks of the XRD pattern was a 


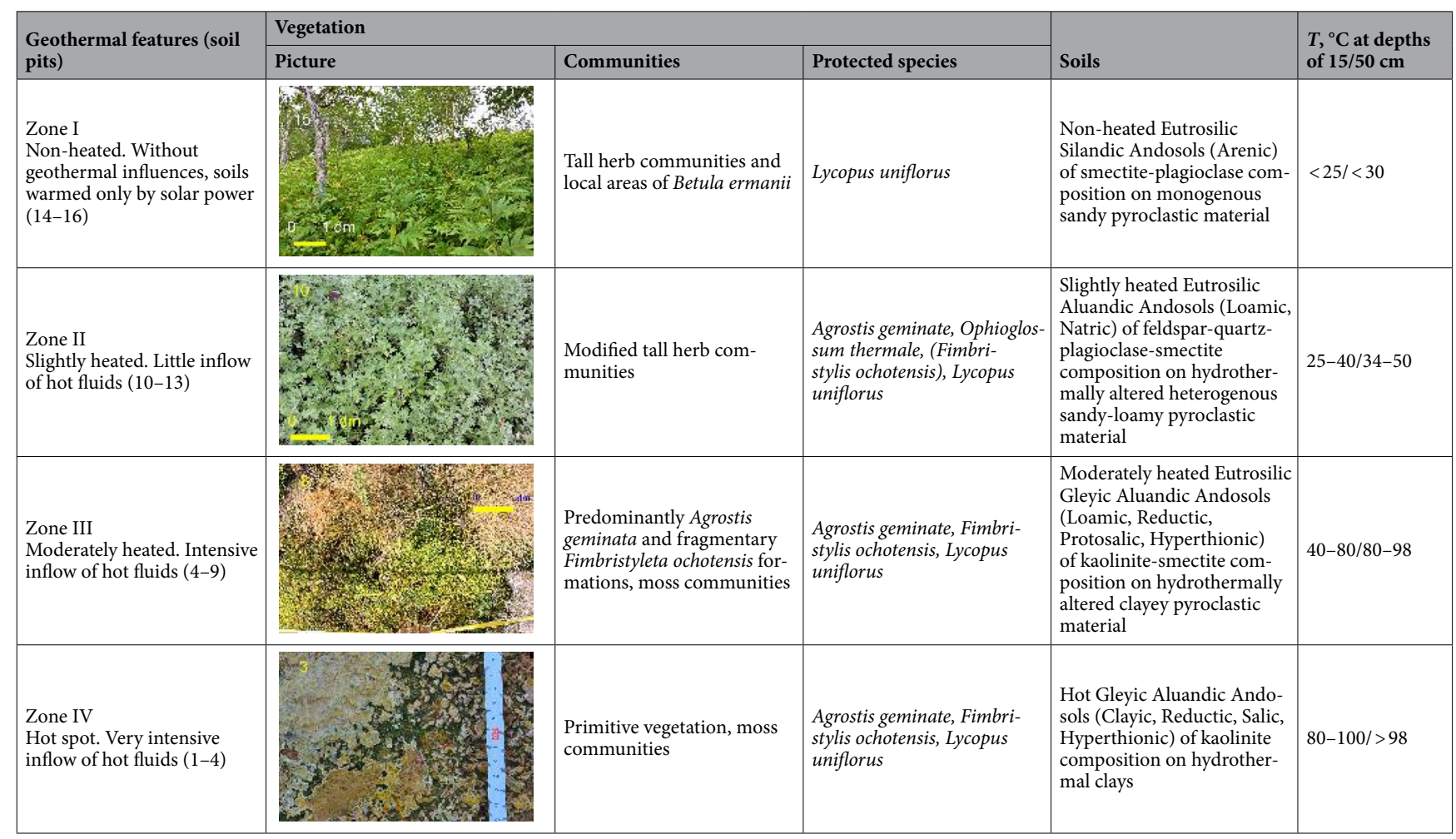

Table 1. Main groups of vegetation and soils studied. Photos by A.V. Zavadskaya.
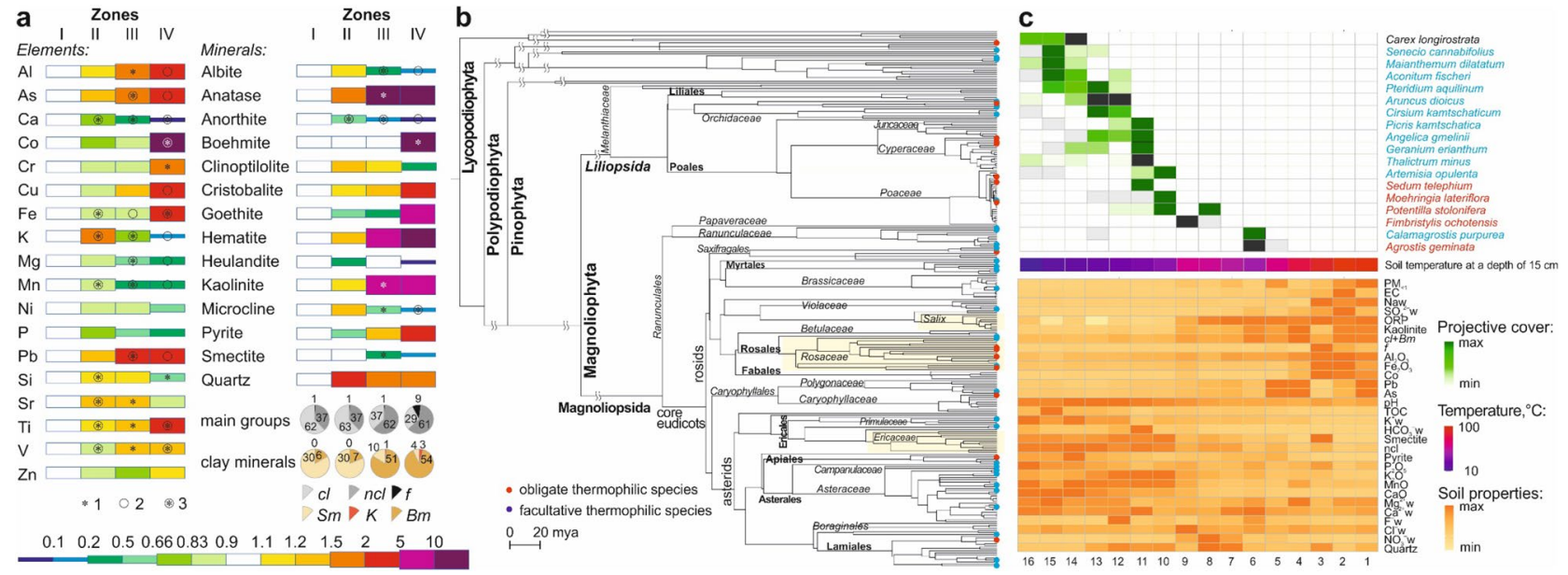

Figure 4. Partition of the topsoil $(0-10 \mathrm{~cm})$ and plants in different thermal zones of catena studied: (a) Element and mineral composition. Significant $(p<0.05)$ differences between composition of soils: 1 -adjacent zones (I and II, II and III or III and IV), 2-zone I and other zones (II, III and IV), 3-in the zone under consideration and composition of soils both in zone I and in a cooler adjacent zone. The concentration of chemical elements and minerals are normalized to the composition in soils of zone I: depletion-blue and green, accumulationyellow and red. Main groups of minerals (100\%): $c$-clay minerals (kaolinite, smectite, boehmite), $n c l-$ nonclay minerals (microcline, albite, anorthite, clinoptilolite, heulandite, anatase, quartz, cristobalite), $f$-minerals of iron (pyrite, hematite, goethite, jarosite, marcasite). Clay minerals (100\%): Sm-smectite, $\mathrm{K}$-kaolinite, $\mathrm{Bm}-$ boehmite. (b) The thermophilic species observed along the catena on the phylogenetic tree of all the vascular plants occurred in the Valley of Geysers. (c) The key factors limiting plant species (black, non-thermal species; blue, facultative thermophytes; red, obligate thermophytes) growth within $1 \times 1 \mathrm{~m}$ plots at the catena studied. $1-16$, numbers of plots. 


\begin{tabular}{|c|c|c|c|c|c|c|c|}
\hline \multirow{2}{*}{\multicolumn{2}{|c|}{ Territory }} & \multirow[b]{2}{*}{ Parent materials } & \multirow[b]{2}{*}{ Temperature, ${ }^{\circ} \mathrm{C}$} & \multirow[b]{2}{*}{ Sampling depth, cm } & \multicolumn{2}{|l|}{ Minerals } & \multirow[b]{2}{*}{ References } \\
\hline & & & & & Rock-forming & $\begin{array}{l}\text { Accessory and } \\
\text { markers }\end{array}$ & \\
\hline \multirow{17}{*}{$\begin{array}{l}\text { Russia, Kamchatka } \\
\text { Peninsula }\end{array}$} & \multirow{4}{*}{ Valley of Geysers } & \multirow{4}{*}{$\begin{array}{l}\text { Rhyolite-dacites or } \\
\text { andesites }\end{array}$} & $30-50$ & $0-40$ and $220-280$ & $\begin{array}{l}\text { Smectite, feldspars, } \\
\text { quartz }\end{array}$ & $\begin{array}{l}\text { Plagioclases, anatase, } \\
\text { zeolites, kaolinite, } \\
\text { cristobalite }\end{array}$ & \multirow{3}{*}{ This study } \\
\hline & & & $50-80$ & $0-25$ & $\begin{array}{l}\text { Kaolinite, anatase, } \\
\text { zeolites }\end{array}$ & $\begin{array}{l}\text { Plagioclases, quartz, } \\
\text { feldspars, smectite }\end{array}$ & \\
\hline & & & $80-100$ & $0-8$ & Kaolinite & \begin{tabular}{|l|} 
Anatase, zeolites, \\
plagioclases, hematite, \\
quartz, cristobalite, \\
feldspars, pyrite, \\
smectite, boehmite
\end{tabular} & \\
\hline & & & 100 & $0-10$ & Kaolinite, quartz & $\begin{array}{l}\begin{array}{l}\text { Halloysite, non- } \\
\text { ordered smectite } \\
\text { (montmorillonite), } \\
\text { clinoptilolite }\end{array} \\
\end{array}$ & 129 \\
\hline & $\begin{array}{l}\text { East Pauzhetka ther- } \\
\text { mal field }\end{array}$ & Andesitic lavas & $20-30$ & $0-70$ & Kaolinite & $\begin{array}{l}\text { Pyrite, a-quartz, } \\
\text { alunite, jarosite, } \\
\text { goethite }\end{array}$ & 58 \\
\hline & & & $35-70$ & $70-250$ & Kaolinite & \begin{tabular}{|l|} 
Pyrite, $\alpha$-quartz, opal, \\
feldspars, marcasite, \\
alunite, jarosite, \\
goethite
\end{tabular} & \\
\hline & & & \begin{tabular}{|l|}
$70-80$ \\
\end{tabular} & $250-290$ & Kaolinite, smectite & - & \\
\hline & & & $80-95$ & $300-350$ & Smectite & $\begin{array}{l}\text { a-Quartz, opal, feld- } \\
\text { spars (albite), pyrite } \\
\text { and other sulfides, } \\
\text { magnesio-calcite }\end{array}$ & \\
\hline & & & $95-100$ & $350-400$ & $\begin{array}{l}\text { Smectite, opal, quartz, } \\
\text { magnesio-calcite }\end{array}$ & Pyrite & \\
\hline & $\begin{array}{l}\text { Upper Pauzhetka } \\
\text { thermal field }\end{array}$ & Andesites & $<98$ & $0-30$ & Kaolinite, limonite & $\begin{array}{l}\text { Dioctahedral smectite, } \\
\text { pyrite, quartz, heu- } \\
\text { landite, plagioclases, } \\
\text { elemental sulfur, } \\
\text { jarosite } \\
\end{array}$ & 134 \\
\hline & & & & $5-50$ & $\begin{array}{l}\text { 'Blue clays': pyrite, } \\
\text { silica (opal, chal- } \\
\text { cedony, quartz) }\end{array}$ & $\begin{array}{l}\text { Jarosite, (hydro) } \\
\text { goethite, hematite }\end{array}$ & \\
\hline & & & & $30(50)-180(200)$ & Montmorillonite & \begin{tabular}{|l|} 
Pyrite, hematite, \\
(hydro)goethite, \\
feldspars, silica (opal, \\
chalcedony, quartz), \\
illite-smectite, \\
chlorite-smectite, \\
magnetite, titanomag- \\
netite
\end{tabular} & \\
\hline & South Kambalnoe & Andesites & $80-95$ & $25-162$ & Smectite ${ }^{* *}$ & $\begin{array}{l}\text { Kaolinite, anatase, } \\
\text { gypsum, opal, hema- } \\
\text { tite, pyrite, gypsum }\end{array}$ & 145 \\
\hline & & Tuffites & & $150-310$ & Kaolinite & \begin{tabular}{|l|} 
Smectite, quartz, cris- \\
tobalite, and opal
\end{tabular} & 5,25 \\
\hline & & & 100 & Topsoil & Opal, quartz, kaolinite & $\begin{array}{l}\text { Alunite, sulfur, } \\
\text { goethite }\end{array}$ & 131 \\
\hline & $\mathrm{Na}$ & Andesites and basalts & 40 & $0-200$ & Opal & \begin{tabular}{|l|} 
Alunite, sulfur, \\
gypsum, pyrite, alum \\
(Al hydrated sulfate), \\
(hydro)goethite
\end{tabular} & 44 \\
\hline & & & $20-100$ & $0-400$ & Kaolinite & \begin{tabular}{|l|} 
Alunite, gypsum, \\
opal, mordenite, \\
pyrite, (hydro)goethite
\end{tabular} & \\
\hline & $\begin{array}{l}\text { North Paramushir } \\
\text { hydrothermal mag- } \\
\text { matic system }\end{array}$ & $\begin{array}{l}\text { Calcareous tuffite and } \\
\text { tuffs }\end{array}$ & $100^{*}$ & $\mathrm{Na}$ & Opal, cristobalite & $\begin{array}{l}\text { Jarosite, hematite, } \mathrm{Fe} \\
\text { hydroxides }\end{array}$ & 129 \\
\hline Russia, Kuril Islands & & & & & $\begin{array}{l}\text { Silica, smectite, chlo- } \\
\text { rite (up to } 25 \% \text { ) }\end{array}$ & Jarosite, gypsum & \\
\hline & & & & & Quartz, alunite & - & \\
\hline $\begin{array}{l}\text { Saint Lucia, Soufriere } \\
\text { Volcanic Centre }\end{array}$ & Sulfur Springs & Dacites & $41-97$ & Surface & Kaolinite, quartz & $\begin{array}{l}\text { Feldspars, cristobalite, } \\
\text { (natro)alunite, jarosite }\end{array}$ & 58 \\
\hline
\end{tabular}




\begin{tabular}{|c|c|c|c|c|c|c|c|}
\hline \multirow{2}{*}{\multicolumn{2}{|c|}{ Territory }} & \multirow{3}{*}{$\begin{array}{l}\text { Parent materials } \\
\text { Travertines }\end{array}$} & \multirow{3}{*}{$\begin{array}{l}\text { Temperature, }{ }^{\circ} \mathbf{C} \\
\mathrm{Na}\end{array}$} & \multirow{3}{*}{$\begin{array}{l}\text { Sampling depth, cm } \\
\text { Surface }\end{array}$} & \multicolumn{2}{|l|}{ Minerals } & \multirow[b]{2}{*}{ References } \\
\hline & & & & & Rock-forming & $\begin{array}{l}\text { Accessory and } \\
\text { markers }\end{array}$ & \\
\hline \multirow{2}{*}{ USA, California } & \multirow{2}{*}{$\begin{array}{l}\text { Little Hot Springs Val- } \\
\text { ley (Lassen Volcanic } \\
\text { National Park) }\end{array}$} & & & & $\begin{array}{l}{ }^{\star} \text { Kaolinite, mont- } \\
\text { morillonite, alunite, } \\
\text { natroalunite, opal, } \\
\text { cristobalite }\end{array}$ & $\begin{array}{l}{ }^{*} \text { Anatase, goethite, } \\
\text { jarosite, hematite, } \\
\text { Fe-sulfate minerals, } \\
\text { native sulfur } \\
\end{array}$ & \multirow{2}{*}{134} \\
\hline & & $\begin{array}{l}\text { Landslides and } \\
\text { colluvial sediments } \\
\text { derived primarily from } \\
\text { andesitic lavas }\end{array}$ & $20-100$ & $0-100$ & Kaolinite, smectite & Alunite & \\
\hline Mexico & $\begin{array}{l}\text { Los Azufres geother- } \\
\text { mal field }\end{array}$ & Pleistocene rhyolite & $\mathrm{Na}$ & Near-surface & $\begin{array}{l}\text { Cristobalite, tridymite, } \\
\text { opal, quartz, kaolinite }\end{array}$ & - & 145 \\
\hline Iceland & $\begin{array}{l}\text { Thermal fields Theis- } \\
\text { tareykir and Namafjall }\end{array}$ & Basaltic hyaloclastites & $>20$ & Surface & $\begin{array}{l}{ }^{*} \text { Pyrite, smectite, } \\
\text { kaolinite }\end{array}$ & $\begin{array}{l}{ }^{*} \text { Anatase, zeolites, } \\
\text { alugene }\end{array}$ & 5,25 \\
\hline
\end{tabular}

Table 2. Mineral associations in soils and parent materials within zones of discharge of steam-heated acidsulfate waters. ${ }^{\star} \mathrm{PM}_{<2}$. ${ }^{*}$ Following reconstruction, with samples taken from cooled areas (the hydrothermal system with regressive trend in the evolution). Markers are in bold.
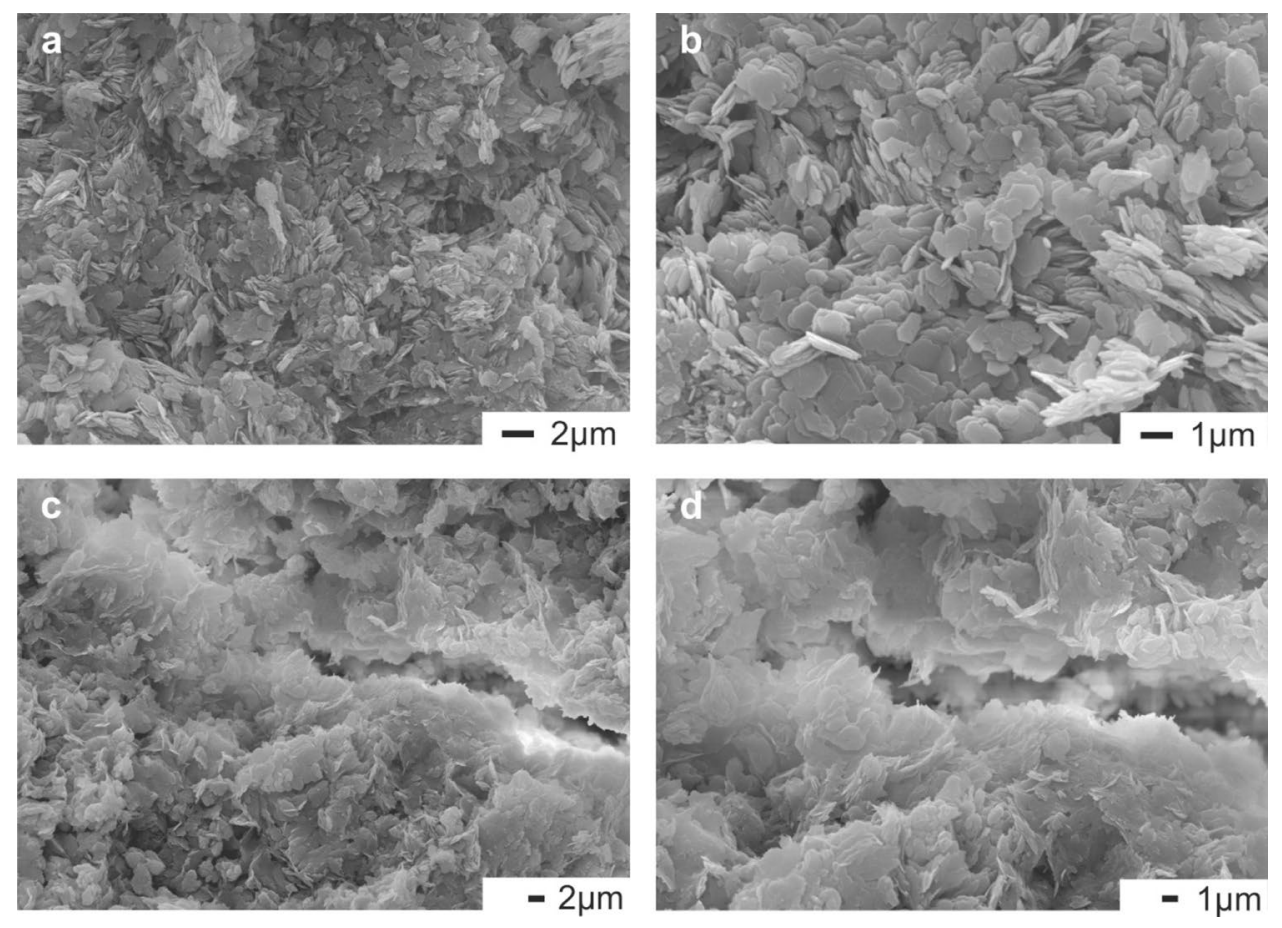

Figure 5. SEM images of clay mass of moderately heated Andosols in the Valley of Geysers: (a) Non-oriented clay matrix from moderately heated Andosols. (b) Pseudohexagonal crystals of kaolinite. (c) Open microcracks in clay matrix. (d) Microaggregates with sheet-like curved shape, composed of kaolinite and kaolinite-smectite particles, which form the walls of open microcracks.

very popular method for assessing the degree of kaolinite order/disorder. However, recent studies ${ }^{39}$ showed that only the analysis of the XRD full pattern was suitable for this. All the studied kaolinites were characterized as low-ordered, since they had poorly defined non-basal $(h, k)$ peaks and the modulation of peaks at large angles $2 \theta$ was almost absent. The low ordering of the studied kaolinite structure was apparently caused by the following reasons: (1) low stacking order of the layers due to certain geological conditions during kaolinite synthesis, (2) occurrence of a small amount (up to 5-10\%) of mixed-layered kaolinite-smectite (K/S) minerals. This was also indicated by the presence of a specific displacement of basal $(00 l)$ peaks after oriented specimen saturation with ethylene glycol (Fig. 3e,f). When calculating the mineral composition, the phases of kaolinite and K/S did not differ.

According to the SEM study of the moderately heated Andosols, the kaolinite had a diverse particle morphology, which obviously showed the degree of its structure order/disorder. Pseudohexagonal crystals of kaolinite (Fig. 5b) were found within a non-oriented matrix (Fig. 5a). In contrast, crystals with poorly defined habitus or with irregular sheet-like curved shape (Fig. 5d) were found in microaggregates oriented along the walls of open microcracks (Fig. 3c). Thus, based on SEM and XRD, we suggested that these were particles of disordered 
kaolinites and kaolinite-smectite mixed-layer minerals. Such elongated aggregates were found in the dense groundmass of the layer (Fig. 2k).

Zone IV. Hot Gleyic Aluandic Andosols (Clayic, Reductic, Salic, Hyperthionic) near the center of the steam hydrotherm. Shallow and hot Andosols with temperatures of $>80^{\circ} \mathrm{C}$ (Figure S2) exhibited a mottled (light gray and reddish) biocrust of thermophilic algae on the surface of a bright-colored clayey Bilz-horizon (Table S2), which was underlain by greenish, bluish and whitish clays (Crz-horizon) formed as a result of a deep hydrothermal alteration and bleaching of volcanic rocks. On a micro-scale, the zone IV topsoil consisted of laminated crusts of silty material impregnated and bonded by collomorphic Fe-Al-organomineral substances with a fluidal $\left(\mathrm{after}^{40}\right)$ texture. Below, the argillized material was very heterogeneous in color (e.g., with whitish mottles corresponding to locally reducing conditions) and contained inclusions of various minerals (Figs. 1i, 2g,h). Such argillized material was typical for the shallow hydrothermal sediments of Kamchatka ${ }^{28,41-43}$ and the Iturup Island ${ }^{27}$. SEM analyses showed that hot Andosols consisted of kaolinite aggregates, pseudomorphs of which had replaced rockforming minerals. The soil microfabric was typical for Kamchatka's hydrothermal clays (Fig. 2l), i.e., inherited from the parent materials ${ }^{25}$, with a high porosity resulting from an intensive rise of vapors from endogenous hot fluids. Such pores were colonized by thermophilic bacteria.

The particle-size distribution of hot Andosols was characterized by the predominance of $\mathrm{PM}_{<5}$ and $\mathrm{PM}_{10-50}$ (Table S8). In comparison with non-heated Andosols, hot Andosols had a lower content of $\mathrm{PM}_{>10}$, lower $\mathrm{pH}$ and SOC values and higher values of Eh and EC due to an intensive inflow of endogenous fluids and the biogenic oxidation of sulfides (Table S7).

Hot Andosols as compared to non-heated Andosols were also enriched in $\mathrm{Ti}, \mathrm{Cr}, \mathrm{Fe}, \mathrm{Co}, \mathrm{Cu}, \mathrm{As}$ and $\mathrm{Pb}$, depleted in $\mathrm{Mn}, \mathrm{Ca}, \mathrm{Si}, \mathrm{K}$ and $\mathrm{Mg}$ and had the similar contents of $\mathrm{V}, \mathrm{Ni}, \mathrm{Zn}, \mathrm{P}$ and $\mathrm{Sr}$ (Table S7). Leaching of $\mathrm{Ca}, \mathrm{K}, \mathrm{Na}$ and $\mathrm{Mg}$ from volcanic rocks was known to be induced by steam-heated acid-sulfate waters ${ }^{44}$, while enrichment in $\mathrm{Fe}, \mathrm{Cu}$ and $\mathrm{Co}$ could be caused by a selective biogenic accumulation of metals (including $\mathrm{Ca}, \mathrm{Mn}$ and $\mathrm{Sr}^{45}$ ) within biocrusts. The impact of steam-heated acid-sulfate waters caused an enrichment of Ti within deep layers of subsurface sediments in Kamchatka ${ }^{46}$ and the formation of mineral coatings on stones in a hot river on the Iturup Island ${ }^{27}$.

The volcanogenic source rocks of the hot Andosols were deeply altered and mostly consisted of poorlyordered kaolinite and kaolinite-smectite mixed layered minerals (Fig. 3e,f) and small amounts of boehmite, anatase and quartz (Table S8, Fig. 21). Most samples of hot Andosols also had considerable contents of potassium feldspars, boehmite, pyrite, cristobalite and hematite. Plagioclases, goethite and zeolites occurred rarely. The smectite content was low, this being the main mineral of soils in non-heated and slightly heated Andosols. Boehmite, jarosite, pyrolusite, marcasite and calcite occurred only in hot Andosols (Table 2). In comparison with non-heated Andosols, hot Andosols were enriched in kaolinite, anatase, hematite and boehmite and impoverished in smectite, potassium feldspars, plagioclases and zeolites (Table S11). A high content of kaolinite and a low content of albite and quartz resulted from the duration of exposure to and/or high temperature of a steam hydrotherm ${ }^{47,48}$.

The microstructure of hot Andosols (Fig. 2l) differed from that of less heated Andosols by the presence of numerous round opal grains, which often formed collomorphic microaggregates, pore infillings and bridges between clay micropeds. At the surface of opal pedofeatures, there were occasional crystals of pyrite, anatase and cristobalite.

Botanical transect description. Within the studied catena, from the periphery of the thermal field with communities (association of Betuletum ermanii calamagrostidosum subassociations typicum or dryopteridosum) on non-heated Andosols to its bare ground center, plant communities replaced each other in the following order: slightly modified tall herb meadow $\rightarrow$ modified meadow with dominance of Thalictrum minus or Pteridium aquilinum $\rightarrow$ communities with dominance of Artemisia opulenta and monodominant communities of Calamagrostis langsdorfi $\rightarrow$ microzonal communities ${ }^{8}$ with dominance of Agrostis geminata, Lycopus uniflorus or Potentilla stolonifera $\rightarrow$ microzonal communities with dominance of the Marchantiophyta (Gymnocolea inflate and Solenostoma vulcanicola $)^{49,50}$ and Fimbristylis ochotensis $\rightarrow$ Marchantiophyta communities $\rightarrow$ biocrust.

The cover of vascular plants dropped at around $60^{\circ} \mathrm{C}$, with cover values not exceeding $20 \%$ above this temperature. Mosses decreased in cover at $65^{\circ} \mathrm{C}$ and disappeared completely at around $90{ }^{\circ} \mathrm{C}$. The total number of species varied from 9 to 24 per $1 \mathrm{~m}^{2}$ on the non-heated soils. With increase in temperature it decreased and did not reach more than 6 species per $1 \mathrm{~m}^{2}$ at a topsoil temperature of more than $43^{\circ} \mathrm{C}$. Thus, together with previous studies $^{51-54}$, our research showed that in the Valley of the Geysers, non-vascular plants dominated at the moderately heated and hot soils.

The clear majority (263 of 292, see Methods) of species belonged to Magnoliophyta. Both facultative (Net Relatedness Index, NRI $=1.7 \pm 0.5, p=0.036)$ and obligate $(\mathrm{NRI}=1.3 \pm 0.8, p=0.084)$ thermal species seemed to be clustered on the phylogenetic tree of Magnoliophyta from the Valley of Geysers (Table S12). However, they did not form a monophyletic clade and were organized in small clusters ${ }^{55}$ of closely related thermal species that were distributed throughout the phylogenetic tree (Fig. 4c).

Only 9 of 60 families of vascular plants contained obligate thermophyte species (Fig. 4c, Figure S3). Rosaceae (4 of 18 species) were overrepresented with a false discovery rate (FDR) level of $15 \%$. The other two families represented by more than one species were Cyperaceae and Poaceae that had been typical for Cenozoic floras of geothermally influenced wetland hydrophytic and dryland mesophytic communities ${ }^{56}$. As far as orders were concerned, only Rosales were overrepresented in the obligate thermal flora (Table S13). 
Among 24 families that contained facultative thermophytes, no families were significantly enriched or depleted in such species. At the level of orders, Poales were underrepresented and Asparageles were overrepresented among facultative thermophytes (Table S13).

Among 6 families containing only thermal species (both facultative and obligate thermophytes) in the Valley of the Geysers, 5 families (Dennstaedtiaceae, Geraniaceae, Urticaceae, Rubiaceae, and Iridaceae) were represented by only one species, and Amaryllidaceae were represented by two species Allium ochotense and A. strictum. Although this was not surprising having a probability of 0.03 to occur by chance, the fact that both these species were thermal may relate to the fact that the main center of Allium genera diversity located in southwest and central Asia ${ }^{57}$ i.e., Allium sp. might serve as an indicator of thermal habitats in Kamchatka.

At the non-heated habitats near the catena, among families of the Valley of Geysers with only non-thermal species, Thelypteridaceae, Equisetaceae and Betulaceae were overrepresented (Table S13). Overrepresented orders were Equisetales, Polypodiales, Fagales and Liliales, while the order Poales was underrepresented. At the class level, the nearest non-thermal flora at non-heated Andosols (group B, see Methods) was enriched with Polypodiopsida species, which could result from the higher humidity of this territory ${ }^{18}$.

Alteration of Andosols under the impact of steam-heated acid-sulfate waters. In the Valley of Geysers, the inflow of hydrothermal fluids into Andosols seemed to cause a decrease in TOC content, salinization (Figure S4), alkalinization (only at the hydrotherm margin), accumulation of $\mathrm{Al}, \mathrm{As}, \mathrm{Co}, \mathrm{Cr}, \mathrm{Cu}, \mathrm{Fe}, \mathrm{Pb}, \mathrm{Ti}$ and $\mathrm{V}$, removal of $\mathrm{Ca}, \mathrm{K}, \mathrm{Mg}, \mathrm{Mn}$ and $\mathrm{Si}$ resulted from acid hydrolysis and a deep mineralogical alteration of the parent materials. The biogenic oxidation of sulfides ${ }^{15,22,23,43,58}$ provided forming of potential acid sulfate soils. A decrease in the TOC content resulted from both a small amount of litter-the projective cover of vegetation decreases from the periphery to the center of the hydrotherm-and sulfuric acid decomposition of organic matter. These processes were typical for endothermal soils affected by the steam-heated acid-sulfate waters in Kamchatka $^{18}$, New Zealand ${ }^{9,59-62}$, Iceland ${ }^{22}$, California ${ }^{37}$, Japan (Hokkaido ${ }^{63}$ and the Kusatsu-Shirane volcano region $\left.^{64}\right)$.

The hydrothermal alteration in endothermal soils was characterized by the transformation of smectite (the predominant clay mineral) to kaolinite, the assemblage of non-clay minerals (albite, anatase, anorthite, clinoptilolite, cristobalite, heulandite, microcline, quartz), a decrease in the proportion of plagioclases (with a relative increase in microcline) and the appearance of noticeable amounts of jarosite and boehmite (Fig. 4c). New mineral phases and an increased proportion of clay in the particle-size distribution were previously reported in endothermal soils of Kamchatka ${ }^{18,24}$, Japan ${ }^{64}$, California ${ }^{37}$, and Iceland ${ }^{5}$.

The A-horizon of the non-heated Andosols had a weakly developed macrostructure and a good microstructure. Due to the more intense alteration of rocks and minerals and a heavier texture, in slightly heated Andosols, the structure was well-developed both at a macro and micro scale. In zones III and IV, the A-horizon degraded to a biocrust. A similar trend was observed in the B-horizon, i.e., the structure was most developed at the hydrotherm's periphery because of the favorable combination of factors such as a loamic texture and the release of bases from weathered primary minerals.

In the topsoil $(0-10 \mathrm{~cm})$, the $\mathrm{SiO}_{2}$ content in zones I-III was typical for non-heated Andosols of Kamchatka ${ }^{65}$, but higher than those in zone IV, where $\mathrm{Al}, \mathrm{Fe}$ and Ti were introduced by hydrothermal fluids and contributed to the formation of disordered kaolinite, anatase, hematite, goethite and boehmite.

Soils with temperatures below and above $50{ }^{\circ} \mathrm{C}$ differed in their mineralogical composition. Soils of zones III and IV had lower contents of plagioclases, mordenite, potassium feldspars and smectite and higher contents of anatase, boehmite, kaolinite and hematite (Table 2). The studied endothermal soils in relation to non-heated Andosols had higher contents of clay minerals and Fe- and S-containing minerals and lower contents of other non-clay minerals: albite, anorthite, clinoptilolite, microcline (Fig. 4c).

Clustering of thermal species on the phylogenic tree. In the Valley of Geysers, the Poaceae (30 species) and Cyperaceae (19) were the most represented families after the Asteraceae (31). But only one Poacea species and no Cyperacea species were among 33 facultative thermophytes, which makes Poales the most underrepresented order among facultative thermophytes (Table S13). Given that this order was the most prevalent among obligatory thermophytes (Table S14), we suggest that there are different constraints of thermophiticity and thermotolerance ${ }^{66}$. And for Poales, specialization was the more preferred way of adaptation to the extreme environment (high acidity, salinity, temperature and clay texture) rather than generalization. According to ${ }^{67}$, Poales and Asterales were over-represented by alien plants on Mediterranean islands due to their late flowering, large seed size and anemochory. The prevalence of the Poales among obligate thermophytes could resulted from their ecological competitiveness ${ }^{68}$. For example, the Poaceae and Cyperaceae are well adapted to drought ${ }^{69}$. Additionally, the Poaceae are well adapted to saline habitats ${ }^{70}$. Data on the fossil floras of ancient hot carbonated springs support the fact that vegetation pre-adapted to chemically and physically stressed environments colonizes heated habitats ${ }^{56}$ i.e., plants occupy free niches.

In the geobotany analysis described above, all the species that occurred in the Valley of Geysers (in areas with either temperature, but had not been found at the catena and at the surrounding territory) were merged in the group of distant territory (both non-heated and heated). It was justified by several reasons. Firstly, the temperature, humidity, salinity and altitude differed throughout the Valley of Geysers ${ }^{1,18}$. And our analysis aimed to compare vegetation of the specific thermal site affected by steam-heated acid-sulfate waters with its surrounding and distant territories represented by all other parts of the Valley of Geysers. Secondly, it appeared to be impossible to clarify which species had been identified as "thermophytes" without a detailed soil temperature survey $i^{71}$ later provided in ${ }^{1,8}$. When we specified species with the status "thermal" in either distant territories (the Geysernaya River valley's plant species list compiled by L.I. Rassokhina: see Table S14) or in the catena studied 
as "thermal" and species with "non-thermal" status in either study as "non-thermal", the results were overlapping, but not the same (Table S15). The Cyperaceae was the overrepresented family among obligate thermophytes, but underrepresented among facultative thermophytes. The Ericaceae and Saxifragaceae tended to be non-thermal (simultaneously overrepresented among non-thermal species and underrepresented among thermal species), while the Caryophyllaceae and Juncaceae were the thermal species (vice versa). 10 of the 12 Ericaceae and all 4 of the 4 Saxifragaceae species were non-thermal; 9 of the 10 Caryophyllaceae and 8 of the 9 Juncaceae species were thermal. We suggested that the differences between the results obtained by the two calculation methods were caused by the diversity of thermal habitats in terms of $\mathrm{Eh}, \mathrm{pH}$, cation-anion composition and salinity of waters, heating and moistening of soils $s^{1,18,24,48}$.

Relationships between the composition of plant communities and soil properties. The depth of plant root occurrence decreased from non-heated Andosols to heated Andosols of zones II and III (Table S2). Plant roots were not found in hot Andosols. In non-heated Andosols, slightly and moderately heated Andosols, the diameter of plant roots decreased, too. We did not notice any features (e.g., horst- or cushion-forming) of underground plant parts or roots that were preserved alive where there was direct contact with heated ground.

In the catena studied, the most drastic changes in soil morphology at the meso-, micro and nano-scales, elemental composition and particle-size distribution occurred when the temperature at a depth of $50 \mathrm{~cm}$ rose above $60^{\circ} \mathrm{C}$, with the most significant mineralogical changes occurring with the temperature transition at $50^{\circ} \mathrm{C}$. The species diversity of the facultative thermophytes changed sharply when the soil temperature at a depth of $50 \mathrm{~cm}$ rose above $98^{\circ} \mathrm{C}$, although that of obligate thermophytes changed only slightly (Figure S5). The pairwise comparison of species compositions from the thermal zones showed that zones II-IV had more similar species than expected by chance and zone I differed significantly from zone II due to the loss of non-thermal species in zones II, III and IV and their high diversity in non-heated areas. At the catena studied and its surrounding territory (both non-thermal and thermal landscapes), the number of obligatory thermophytes gradually decreased with an increase in temperature, while the number of facultative thermophytes remained the same in zones II and III and sharply decreased in zone IV that could have resulted from the absence of any visible morphological adaptations, for example (Figure S5).

The absolute majority of the thermophilic vascular plants were mesophytes and not psychrophytes in relation to temperature and humidity, respectively (Table S16). In comparison to non-thermal flora, there were no overrepresented or underrepresented biomorphs (Fisher's exact test, $p$ value $>0.05$ ).

Based on the relationships between the cover values of plants and edaphic conditions at the catena we distinguished 11 ecological groups of species (Table S17-S19). The main edaphic factors limiting plant growth included $\mathrm{EC}$, the content of sulfates in water extract, particle-size distribution and $\mathrm{pH}$. Even for the thermal zones, such factors as the soil temperature, SOC content, concentration of toxic compounds and Eh were less important.

In thermal landscapes, biodiversity can increase or decrease depending on the maximal temperature at the certain hotspot. When a temperature of heated neutral solutions is low (less than $30^{\circ} \mathrm{C}$ ) e.g., in the Bolshezemelskaya tundra (Russian Subarctic) ${ }^{72}$, due to higher frequency of soil freezing-thawing, environmental harshness may result in decrease in the floristic and microbiota richness. Such a partition was observed at the Hengill valley in Iceland ${ }^{73}$. In the South Sandwich Islands (maritime Antarctic), bryoflora richness was maximal at the thermal ecosystems where the topsoil surface temperature reached $47^{\circ} \mathrm{C}^{74,75}$. In the forest landscapes of Kamchatka ${ }^{76}$, Hokkaido $^{48,77}$, California ${ }^{37}$ and New Zealand $d^{7,9,61,62,78}$, the inflow of heated thermal waters resulted in disappearance of woody plants. Vegetation was sparse at the endothermal soils with surface temperatures of more than $50{ }^{\circ} \mathrm{C}$. In thermal ecosystems, the highest vascular plant ${ }^{79}$ and moss ${ }^{80}$ species richness was typical for areas where the topsoil temperature is $30-40$ and $30-50^{\circ} \mathrm{C}$, respectively due to the upper thermal limit for cell activity lied between 45 and $55^{\circ} \mathrm{C}$.

The subsoil temperature seems to be the main factor controlling the vegetation of geothermal areas, while soil chemical factors are thought to have less influence $e^{1,8,81-84}$. Because soil temperature is the simplest and most reliable indicator to assess the plant partition at thermal ecosystems during the field study, other environmental factors (e.g., pH, soil moisture, a content of phytotoxic substances) were studied insufficiently. But soil temperature affects the vegetation together with other physical and chemical soil properties that also depend on the intensity of the inflow of heated fluids and waters. A relationship between the vegetation and the environment has only been analyzed based on the data collected at transects from a center of a hydrotherm to its periphery. However, such approach does not allow separating the influence of soil temperature and chemical properties on vegetation as these factors are dependent variables. To understand the role of soil temperature and chemical properties on plant growth separately, more detailed sampling should be carried out into one thermal zone.

\section{Materials and methods}

Study area. The narrow and deeply incised valley of the Geysernaya River has been hiding from human eyes remarkable and unique natural objects until its discovery in April 1941 by an employee of the Kronotsky Reserve, geologist Tatiana Ustinova (1913-2009). Since its discovery and due its location within the Kronotsky Federal Nature Biosphere Reserve, securing the highest level of protection of unique ecosystems and creating opportunities to use them as etalons for studying undisturbed course of events, the ecosystem of the Valley of Geysers became one of the most popular objects for scientific investigations.

The Valley of Geysers and the Uzon Caldera are located $180 \mathrm{~km}$ northeast of Petropavlovsk-Kamchatsky City and surrounded by volcanoes, arranged in a chain along the eastern coast of the Kamchatka Peninsula within the so-called Eastern volcanic belt, being part of the Pacific Ring of Fire ${ }^{85}$. The Valley of Geysers is the second largest geyser field in the world (Fig. 1a) after the Yellowstone National Park ${ }^{32,48,86}$. More than 100 described 
geysers and about the same number of dwarf and unnamed geysers are located on an area of 50 thousand $\mathrm{m}^{277}$. According to ${ }^{87}$, their total number exceeds 200.

Geology. Geologically, the hydrothermal system of the Valley of Geysers is situated within the margin of the Uzon-Geyser Caldera, where acidic crustal volcanism has developed over the last $40 \mathrm{ka}^{1}$. The studied territory on the left (east) side of the Geysernaya River with various thermal springs including geysers is a part of the depression named Geysernaya caldera ${ }^{88,89}$ - the oldest part of the caldera system, the age of which is estimated at $\sim 280 \mathrm{ka}^{90,91}$. In the Geysernaya River valley, andesitic tuffs and lacustrine sediments are the main parent materials ${ }^{92,93}$, i.e., Geysernaya and Pemzovaya units $\left(\mathrm{Q}_{3}{ }^{4} \mathrm{gr}, \mathrm{pmz}\right)^{89,94}$. An intensive drainage of heated water began $9-12 \mathrm{ka}^{1,24}$, when the formation of the studied ecosystems had probably started.

Climate. According to the Köppen-Geiger classification, the climate of Kamchatka is characterized as Dfc ${ }^{18,41}$ with a mean annual precipitation of $2000-4000 \mathrm{~mm}^{1}$. In the studied part of the Geysernaya River valley (Fig. 1bd), there is a persistent characteristic smell of $\mathrm{H}_{2} \mathrm{~S}$ due to its permanent release from the ground (Table S20). The soil temperature regimes range from frigid in the non-thermal areas to hypothermic within the center of the parahydrotherm.

Soils. The Geysernaya River valley is located at the boundary between the Central Soil Province with pyroclastics of a rhyolite-dacite composition (where the youngest andesitic ashes are from the Opal Volcano erupted in 606 BC) and the Northern Soil Province with andesite ashes ${ }^{24}$, where Vitric Andosols (Arenic) ${ }^{95}$ with contents of oxalate-soluble $\mathrm{Fe}$ and $\mathrm{Al}$ of $0.8-1.8 \%{ }^{44}$ are formed. The water enters the hydrothermal system from meteoric sources and moves rapidly through the permeable rock and fractures to where it is heated by the magma. The water composition of the geysers and hot springs (Table S1) varies from sodium-chloride to magnesiumcalcium-sulfate(-hydrocarbonate) types ${ }^{96}$.

The first systematic soil survey of the Geysernaya River valley was conducted by Danila Kostuk and headed by Anna Zavadskaya in 2010 and provided information for the soil mapping of the territory (Fig. 1b $)^{97}$. Descriptions of some of the soil samples and/or pits from the Geysernaya River valley were represented in ${ }^{98}$.

Thermally induced variability in soils and vegetation. For the non-heated Andosols, the vegetation of the Geysernaya River valley is represented by tall-grass, forest and prostrate shrub (i.e., stlanik) communities including Betula ermanii, Salix udensis and Alnus kamtschaticae ${ }^{9,53,59,61,99,100}$. Increasing influences of endogenous fluids and temperatures within a distance of up to $50 \mathrm{~m}$ are accompanied by a transition from non-heated Andosols (Arenic) with several buried soils under tall herb communities to hot Gleyic Andosols (Clayic) (Table 1) that can support only thermoacidophile species $953,82,84,101,102$. Slightly heated surfaces are colonized by Kamchatka's tall herb communities (e.g., Filipenduleta camtschaticae, Calamagrostideta langsdorffi and Saussurieto pseudotilesii-Geranieta erianthis), while moderately heated Andosols are occupied predominantly by thermophyte mosses $^{4,9,60,61,78,101,103,104}$. Biocrusts, which are formed within Kamchatka's hot spring and hydrothermal field areas due to the activity of Cyanidium caldarium ${ }^{53,105}$, also include Streptomyces and other actinomycetes ${ }^{54}$. Aerobic autotrophic sulfur-oxidizing bacteria of the genus Sulfurihydrogenibium (phylum Aquificae) are dominant in most streams of the Valley of Geysers. Another widely distributed group is anaerobic bacteria of the genus Caldimicrobium (phylum Thermodesulfobacteria). Archaea of the genus Vulcanisaeta are abundant in slightly acidic hot springs, where they are accompanied by numerous Nanoarchaeota ${ }^{63}$.

Geothermal vegetation. The vegetation cover of geothermal areas is represented by so called geothermal vegetation, which has characteristics determined by the current and former input of geothermally-derived energy (heat) or materials e.g., solid, fluid or gas ${ }^{99}$. Previous studies have outlined the fundamental role of soil-chemical composition and temperature in influencing the establishment and growth, spatial structure and composition of geothermal vegetation ${ }^{102,106,107}$.

In geothermal areas, plant communities occupy habitats with very specific soil temperatures and replace each other in a particular order. Spatial distribution patterns depending on the soil temperature have been observed in vegetation communities surrounding geothermal features elsewhere in the world: in New Zealand ${ }^{8,82}$, Iceland ${ }^{56}$, Canada $^{53}$, Hokkaido $^{49}$, Italy $^{63}$, the Yellowstone National Park ${ }^{7,101,102,107}$ and the Kamchatka peninsula ${ }^{108}$. Thus, the spatial distribution of communities reflects the configuration of the thermal fields. On the periphery of thermal fields, on the slightly heated soils, plant communities cover considerably large areas. Closer to the hottest area of the thermal field with moderately heated and hot soils, vegetation forms small mosaics of specific geothermal communities. As the size of such geothermal plant communities in most cases is extremely small (less than 1 $\mathrm{m}^{2}$ ), they are named "microzonal thermophilic complexes"20,21.

Geothermal vegetation is usually floristically very simple $8,50,81,82,109-111$ and dominated by bryophytes in Iceland $^{4,53,61,62,101}$, NE Kamchatka peninsula ${ }^{1,112}$ and Japa ${ }^{51-54,63,84,101}$, by grasses and herbs in the Yellowstone National Park ${ }^{53,78,99,106}$, the SE East-European plain ${ }^{53}$, the Baikal rift zone $e^{60,81,83,109,113}$ and Kamchatka peninsula ${ }^{109}$ or by woody vegetation in New Zealand ${ }^{109}$. Such geothermal communities often contain endemic and threatened species $^{60,113}$.

Patterns in vegetation structure, appearing with temperature and soil-chemical composition gradients of thermal fields have been observed by numerous authors ${ }^{71,81,113}$. Overall, the total vegetation cover of communities tends to decrease as the temperature increases, but with plant groups responding differently. Vascular plant cover tends to drop in different geothermal areas at the temperature range of around $45-60{ }^{\circ} \mathrm{C}$ (here and further measurements of substrate temperature at depth of 10-15 cm used for describing soil temperature gradient). Their total cover reduces rapidly above this temperature. Mosses tend to have a higher limit of tolerance to the 
surface temperature. They decrease in cover at $55-65^{\circ} \mathrm{C}$ and disappear in different geothermal sites at around $75-95^{\circ} \mathrm{C}^{60,114}$. The total number of vascular plants within a geothermal ecosystem is inversely proportional to the surface temperature: being greatest at non-heated or slightly heated soils surrounding geothermal areas, it decreases as the temperature rises, and reaches less then several species per plot with moderately heated or hot soils. So, non-vascular plants dominate geothermal highly heated areas, as the tolerance of normal plant cell activity of vascular plants ranges from between 45 and $55^{\circ} \mathrm{C}^{82,115,116}$.

Studies of species distribution in geothermal areas have allowed to suggest classifications of plant species according to the soil temperature of the habitat ${ }^{1,24}$. Generalizing these classifications, the following groups of plants of geothermal areas can be distinguished:

(1) Plants occurring only in geothermal habitats with extreme environmental conditions, or "obligate (extreme) thermophiles"117;

(2) Plants which are able to tolerate conditions within geothermal habitats, but may also occur in neighboring non-geothermal vegetation, or "facultative thermophiles"118;

(3) Disjuncts-plants outside their normal latitudinal and altitudinal range with warmer climate, which establish in geothermal sites as they mimic aspects of its usual habitats ${ }^{119}$;

(4) Plants on the periphery of the geothermal feature;

(5) Ruderal plants.

In relation to the latter group of plants, many authors noticed the very high susceptibility of slightly warm and warm geothermal habitats for weed invasion and the necessity of preserving the native plant communities and species of such thermal sites ${ }^{120,121}$. Some studies showed strong negative correlations between species abundance and surface temperature, and proposed using these plants as indicators of change in the underlying geothermal conditions $^{120,121}$ and for mapping soil temperature ${ }^{122-124}$.

Although regional case studies mentioned above found many general patterns in vegetation structure and composition change along environmental gradients in geothermal areas, all the authors emphasized that their fundamental characteristics are specific for each geothermal field or region and need to be studied in detail for each region. And while relationships between vegetation changes and soil surface temperature have been well described and understood in the majority of geothermal regions, less attention have been paid to studying the influence of other environmental factors on the vegetation of distinct ecosystems of thermal fields. Our study aims to help fill this gap for the Valley of the Geysers in Kamchatka.

Field work. On the left (east) bank of the Geysernaya River, on a catena slope with a height difference of $2 \mathrm{~m}$ and length of $30 \mathrm{~m}$ from the periphery to the center of the thermal site, we studied the vegetation within $1 \times 1 \mathrm{~m}$ plots (Fig. 1, Figure S6), and 18 soil pits (Table S1, Figure S1), from which a total of 65 samples were collected in the NW of geyser Bolshoi and in the SE of geysers Shchel, Grotik, Vrata Ada, Kotly, Vanna, mad pot Krasny and lakes Utinoye and Teploye (Table S21). We selected a catena that was a good representation of the typical ranges for soils and plant communities observed around a hot $\operatorname{spot}^{125}$ and met all the following criteria: round-like shape; size sufficient for digging soil pits and characterizing $1 \times 1 \mathrm{~m}$ plots at least in triplicates in all the thermal zones (I-IV); minimized influence of other hydrothermal fields and hot springs, tourist activity and consequences of landslides.

Color was described in field-moist soils, using ${ }^{126}$. Soil temperatures were measured at depths of 15 and $50 \mathrm{~cm}$ using a TekhnoAs TK-5 contact thermometer (Russia). Soil descriptions were performed in accordance with ${ }^{39}$. Soils and horizons were named using ${ }^{123}$.

The vertical gradient of temperatures within a layer of $0-50 \mathrm{~cm}$. In the non-heated area (pits 14, 15 and 16 in Zone I, Fig. 1d), the temperature of the non-heated Eutrosilic Silandic Andosols (Arenic) did not exceed $30^{\circ} \mathrm{C}$ even at a depth of $2 \mathrm{~m}$ (Figure S2). Equation (1) Describes the change in soil temperature with angle $\alpha=\operatorname{arctg}(\mathrm{k})$ values of $4.6-5.2^{\circ}$.

$$
\mathrm{T}_{0}=\mathrm{kd}+\mathrm{T}_{15}
$$

where $\mathrm{T}_{0}$-temperature of the analyzed soil layer, $\mathrm{d}$-depth between $0-50 \mathrm{~cm}, \mathrm{~T}_{15}$-temperature at a depth of $15 \mathrm{~cm}$.

As compared to non-heated Andosols, the slight heating of Andosols (Loamic) in Zone II (Table 1) was confirmed by significantly $(p=0.034)$ increased $\alpha$ values $\left(10-19^{\circ}\right)$ and temperatures of $34-54{ }^{\circ} \mathrm{C}$ at the depth of $50 \mathrm{~cm}$. Moderately heated Andosols (Loamic) in Zone III were characterized by even more significantly $(p=0.011)$ increased a values $\left(23-37^{\circ}\right)$. Specifically, zone III soils were characterized by relatively cool $\left(60-80^{\circ} \mathrm{C}\right)$ upper layers and hot $\left(>80^{\circ} \mathrm{C}\right)$ lower layers. In the upper $50-\mathrm{cm}$-thick layer of hot Andosols (Clayic) in zone IV, temperature was evenly distributed or, at the zone's periphery, increased with depth from 90 to $100^{\circ} \mathrm{C}$.

Soil analyses. For the chemical analyses, bulk soil samples were collected from all soil horizons, air dried and sieved through a sieve with a mesh size of $1 \mathrm{~mm}$ as recommended in $^{40}$. Particle-size distribution, element composition, redox potential (Eh) and SOC content were determined (Table S22). Water extract analyses including $\mathrm{pH}$ in suspension, electrical conductivity, basicity from $\mathrm{HCO}_{3}{ }^{-}$and the cation-anion composition were also performed in filtrates (Table S22). The cation-anion composition of water extracts was determined by high performance ion chromatography (HP-IC). The particle-size distribution was characterized using the Russian system of particle sizes $(\mu \mathrm{m})$ developed by N.A. Kachinskii ${ }^{127}$ : $1000-500\left(\mathrm{PM}_{500-1000}\right.$, coarse sand), 500-250 
( $\mathrm{PM}_{250-500}$, medium sand), 250-50 ( $\mathrm{PM}_{50-250}$, fine sand), 50-10 ( $\mathrm{PM}_{10-50}$, coarse silt), 10-5 ( $\mathrm{PM}_{5-10}$, medium silt), 5-1 ( $\mathrm{PM}_{1-5}$, fine silt) and less than $1\left(\mathrm{PM}_{1}\right.$, clay).

The mineralogical composition (phyllosilicates and other minerals) of bulk soil samples and clay fractions $(<1 \mu \mathrm{m})$ was determined using 'Ultima-IV' and 'Rigaku' X-ray diffractometers (XRD). Minerals were identified by comparing the data obtained with standard XRD patterns from the PDF-2 database with the use of the MDI Jade-6.5 software (https://materialsdata.com/prodjd.html) and methodological recommendations ${ }^{119}$. Quantitative mineralogical analysis was carried out using the Rietveld full-pattern fitting method ${ }^{29,128-133}$ and the PROFEX GUI for the BGMN software ${ }^{5,58,134,135}$ as modern tools (used in soil science since 2009) for the most precise quantitative assessements of the mineralogical composition of a sample. Investigation of di-tri species of clay minerals and degree of deffects (ordering/disordering) of kaolinite minerals were carried out on non-oriented powder samples (Table S23) ${ }^{136}$. Investigation of expandable minerals was made according to routine procedure ${ }^{137}$. Composition of mixed-layered minerals and ratios of kaolinite and kaolinite/smectite were determined for soils in zones III and IV.

Based on the macromorphological analyses (Table S2) and the primary processing of data on the chemical and mineralogical composition of soils, we selected representative soil pits (1, 7, 11 and 16, Figure S2, Fig. 1) for more detailed micromorphological studies and extractions of exchangeable and oxalate-soluble compounds.

Micromophological analysis of thin sections were performed using standard techniques and an Olympus BX51 polarizing microscope (Japan) with an Olympus DP26 digital camera and specialized computer software. Soil microfabrics of main genetic horizons were compared by analyzing large $(4 \times 5 \mathrm{~cm})$ thin sections with replications. The international terminology for micromorphological descriptions was used ${ }^{138}$.

Based on the results of above analyses, five samples were selected for detailed investigation using a LEO 1450VP scanning electron microscope (SEM) equipped with an INCA 300 microanalyzer (Carl Zeiss, Germany). Field-moist samples were dried using the vacuum freeze-drying technique and their micro/nano structure and composition then studied.

Short-range-order $\mathrm{Al}_{\mathrm{ox}}, \mathrm{Fe}_{\mathrm{ox}}, \mathrm{Si}_{\mathrm{ox}}$ compounds (Figure S7) were extracted after shaking the soil with a $0.2 \mathrm{M}$ ammonium oxalate solution buffered at $\mathrm{pH} 3.0^{127}$. Exchangeable compounds were extracted using an ammonium acetate buffer at $\mathrm{pH} 7.0^{139}$. The element composition of both extracts was determined using an 'iCAP-6500'inductively coupled plasma atomic emission spectrometer by 'Thermo Scientific' (USA).

Data processing. Characteristics of soil properties. The mineralogical composition was assessed using the parameters of clinoptilolite and heulandite as varieties of zeolite, albite and anorthite as varieties of plagioclases and microcline as a representative of potassium feldspars. The above mentioned minerals (clinoptilolite, heulandite, albite, anorthite, microcline) are the most likely to occur in volcanic materials affected by hot fluids (Table 2), according to the results of previous studies in Kamchatka ${ }^{109}$ and other regions of the world ${ }^{140}$.

To reveal changes in soil properties, data were grouped based on the following criteria:

1. Locations of soil pits within thermal zones I-IV (Fig. 1, Table 1, Table S2);

2. Temperatures $\left({ }^{\circ} \mathrm{C}\right)$ of specific samples, i.e., $<30$ (non-heated), 30-50 (slightly heated), 50-80 (moderately heated) and $>80$ (hot);

3. Soil sampling depth.

Descriptive statistics were computed using R software (version 4.0.3, h ttps://www.R-project.org/) ${ }^{141}$. To analyze differences between mean values, the one-sided p-level Mann-Whitney U test was applied, with Bonferroni correction for multiple tests, regarding values with $p<0.05$ as significant.

Degrees of alteration of parent materials were assessed with the use of weathering indices-silica-titanium index (STI) $)^{141}$ and Silica/ $\mathrm{R}_{2} \mathrm{O}_{3}{ }^{142}$ :

$$
\begin{gathered}
S T I=\frac{\mathrm{SiO}_{2}}{\frac{\mathrm{SiO}_{2}}{\mathrm{TiO}_{2}}+\frac{\mathrm{Al}_{2} \mathrm{O}_{3}}{\mathrm{TiO}_{2}}+\frac{\mathrm{SiO}_{2}}{\mathrm{Al}_{2} \mathrm{O}_{3}}} \times 100 \\
\text { Silica } / \mathrm{R}_{2} \mathrm{O}_{3}=\frac{\mathrm{SiO}_{2}}{\mathrm{Al}_{2} \mathrm{O}_{3}+\mathrm{Fe}_{2} \mathrm{O}_{3}+\mathrm{TiO}_{2}}
\end{gathered}
$$

Characteristics of plant communities composition. Comparison of species composition between thermal zones. Data on the species composition of plant communities were represented by three groups as follows: data on the studied catena (group T), its surrounding territory (group B; Figure S6) and all flora of the Geysernaya River valley (group Ya + R) (Table S14). Group T included 29 species of vascular plants recorded during the present study at 18 points corresponding to soil pits within the catena (Table S24). Group B included 66 vascular plant species (58 Magnoliophyta, 7 Polypodiophyta and 1 Lycopodiophyta species) recorded by M.V. Prozorova and A.V. Zavadskaya ${ }^{55}$ during botanical surveys of 178 plots on the left bank of the Geysernaya River-in thermal fields (including the studied catena) as well as non-heated territories. Group Ya $+\mathrm{R}$ included 292 species of vascular plants with their ecology and habitats (e.g., hydro-, hygro-, meso-, xero-, petro- and psychrophytes) recorded throughout the flora of the Valley of Geysers as a result of long-term studies by L.I. Rassokhina ${ }^{1}$ supplemented by her own unpublished data. 
Thermophyte species of the Valley of Geysers were subdivided into obligate (occurring only in heated habitats ${ }^{119}$ ) and facultative (observed both in heated and non-heated habitats). The datasets analyzed were as follows: 1. groups $\mathrm{T}$ and $\mathrm{B}, 2$. all groups $(\mathrm{T}, \mathrm{TB}, \mathrm{Ya}+\mathrm{R})$ and 3. distant territory.

Under- and overrepresentation of taxa in groups of plants. To identify which plant taxa (families, orders and classes) were significantly overrepresented/underrepresented in a group, for each taxon (for each family, order and class, respectively) we calculated the probability of selecting the same or more/less species from this taxon from the entire species pool of the Valley of Geysers. Assuming that there are $N$ species in a species pool, of which $K$ are from the taxon under consideration, and there are $n$ species in a group, of which $k$ are from this taxon. The probability $p_{(k)}$ that $k$ species from this taxon have occurred in the group by chance is calculated with the formula of hypergeometric probability:

$$
p(k)=\frac{C_{K}^{k} \times C_{N-K}^{n-k}}{C_{N}^{n}}
$$

Then the probability Pover for $k$ or more species from this family to occur in this group by chance is a sum of $p(i), i \in[k, \min (K, n)]$, and the probability $\mathrm{P} u n d e r$ for $k$ or less species from this family to occur in this group by chance is a sum of $p(i), i \in[0, k]$.

If Pover (Punder) is low, it is unlikely that $k$ or more (less) species from this taxon can appear among $K$ species in the group by chance. We assumed that taxa with Pover $\leq 0.05$ for a particular group were overrepresented in it, and taxa with Punder $\leq 0.05$ for a particular group were underrepresented in it.

Calculations were made using custom Perl scripts.

Phylogenetic clustering of thermal species. As a measure of clustering of thermal species on a phylogenetic tree of the Valley of Geysers vascular plants, we calculated the net relatedness index-NRI ${ }^{1}$ :

$$
\mathrm{NRI}=-1 \times \frac{\text { MPDobs }-\min (\text { MPDexp })}{\mathrm{SD}(\text { MPDexp })}
$$

To calculate NRI, it was necessary to first compute mean observed pairwise phylogenetic distances (MPDobs) between species from the set. Due to computational difficulties ${ }^{128}$-if species formed more than 100 pairs-we randomly took 100 of them to calculate MPDobs, and took all pairs otherwise. To make a null distribution for MPD (MPDnull), we randomly subsampled the same number of pairs from the entire species pool represented in the phylogenetic tree for 10,000 times. In addition to NRI, we estimated a significance of phylogenetic clustering by ranking MPDobs in the distribution of null values. To account for stochasticity of subsampling, we repeated the whole procedure 10 times for each phylogenetic tree and calculated median NRI and $p$ value over these 10 replicates.

NRI is a standardized mean phylogenetic distance (MPD) between all pairs of species from the same group, multiplied by -1 . NRI is positive when species from a group are clustered on a phylogenetic tree (i.e., species from the group tend to be closely related), and negative when species are evenly spread across a phylogenetic tree. The significance of this relatedness can be obtained by ranking the observed MPD in comparison with the distribution of null values.

We built phylogenetic trees of 292 vascular plants species found in the Valley of Geysers based on a phylogenetic tree from ${ }^{24}$. From our species pool, 224 of 292 species were already present in the tree. Then we added 68 remaining species from our species pool to the tree by adding their branches using 3 different methods with R scripts provided in $^{119}: 1$. as basal polytomies within their families, 2 . randomly within their families, 3 . based on Phylomatic ${ }^{130}$. Furthermore, we calculated NRIs for each group of species using each tree with custom Perl scripts and averaged the results from 3 trees. Separately, we performed the same procedures on 263 Magnoliophyta plants that have been found in the Valley of the Geysers.

Calculations were made using custom Perl scripts. Comparison of species composition between thermal zones. For each pair of thermal zones I-IV, we estimated the significance of having more similar species content than it would be for the random sampling of the same number of species from the list of all species that were found on 178 experimental plots (groups T and B) ${ }^{29}$. For each pair of zones (namely, zone I with $N$ species and zone II with $M$ species), the null distribution of number of common species between the two zones was constructed by subsampling of $N$ and $M$ species from the species pool for 1000 times. Then a right-sided and left-sided $p$ value was obtained by calculating the fraction of subsamplings with the same or more/less common species, respectively than it was in the real data (Tables S13, S15). A low right-sided or left-sided $p$ value means that the species contents in the two zones are more or less similar than in case where all species were spatially mixed. Phylogenetic trees were reconstructed made in R version 4.0.3 (2020-10-10) ${ }^{136}$. Calculations were made using custom Perl scripts.

Evaluation of limiting edaphic factors for plants. To identify edaphic factors which limit the distribution of plant species in the Geysernaya River valley (Tables S17, S18), we analyzed 81 soil properties (some of which were correlated) including particle-size distribution, chemical and mineralogical composition, Eh, $\mathrm{pH}$ and water extract composition in combination with the cover values of 28 vascular plant species (group T) recorded at 12 points within the studied catena. We evaluated the importance of each soil property for each of those 28 vascular plants by calculating the correlation (in $\mathrm{R}$ environment) between the species cover values and the soil parameter value 
within a plot. For a monotonic correlation, we applied Spearman's correlation test from the default functional set of R, and for a non-monotonic correlation, we applied Hoeffding's test with the "Hmisc" package ${ }^{143}$.

Soil parameters that showed positive or negative correlations with the cover values of species with $p \leq 0.01$ were considered as important for this species. Soil properties particularly important for obligate and facultative thermophyte species were identified using Fisher's Exact Test with $\mathrm{R}^{136}$, which showed whether the property was important for more thermophyte species than randomly expected.

\section{Conclusion}

The presented data on soil morphology, chemistry and mineralogy can be used for substantiating the taxonomic position of endothermal soils and to characterize the habitats of rare species of organisms. In the Valley of Geysers, depending on soil properties, elemental and mineralogical composition and the degree of hydrothermal alteration-at the macro-, meso- and micro-scales-under the influence of steam-heated acid-sulfate waters, we have distinguished four variants of Andosols. Non-heated Andosols (soils studied at zone I) are considerably different from thermally influenced Andosols in zones II-IV. We propose:

1. Using in the FAO-WRB system ${ }^{133,144}$ of soil temperature as a diagnostic feature that is obligate for soils occurring at/near hydrotherms.

2. Using the supplementary qualifier 'thermic' in the FAO-WRB system ${ }^{133,144}$ for soils with a temperature $\geq 50^{\circ} \mathrm{C}$ at a depth of $50 \mathrm{~cm}$ and the subqualifier hyperthermic for soils with a temperature $\geq 80^{\circ} \mathrm{C}$;

3. Definition of a new diagnostic horizon (e.g., the Narcisic horizon from Latin Narcissus, for its beauty) as a horizon consisting of mineral material and all of the following:

a. Bright Munsell color in moist state; hue $\geq 5 \mathrm{R}$, value $\geq 3$, chroma 6-8;

b. Soil temperature $\geq 50{ }^{\circ} \mathrm{C}$ at a depth of $50 \mathrm{~cm}$;

c. Loamy texture or finer;

d. Mineral composition dominated by kaolinite.

An additional feature is a fluidal texture in reflected light (Munsell color; hue $\geq 5 \mathrm{R}$, value 2.5-4, chroma 4-8), indicating the presence of intrusive ferruginous pedofeatures.

4. Definition of a new Reference Soil Group -Narcisols having a Narcisic horizon starting $\leq 100 \mathrm{~cm}$ from the soil surface.

Despite Narcisols are among the least extensive Reference Soil Groups on earth, they provide many important functions, including highly valuable environmental services: the picturesque thermal landscapes that attract tourists, provide habitats for endangered, unique and protected plant species and microorganisms with unique metabolic pathways. Unfortunately, these unique soils are threatened with destruction serving as renewable or 'green' sources of energy, as these soils are fragile and restore slowly.

In the Valley of Geysers, the Rosaceae, Poales and Rosales species are the most prevalent among the obligate thermal flora. Poales species from the Poaceae and Cyperaceae families are obligate thermophytes rather than facultative thermophytes, which highlights the different mechanisms of these ecological strategies. Pteridophytes tend to be overrepresented in the nearest non-heated habitats to thermal fields due to high humidity. On the phylogenetic tree of Magnoliophyta for the Valley of Geysers, thermophytes form small clusters of closely related thermal species, which are distributed throughout the evolutionary tree. The thermally influenced area can be distinguished from the non-thermally influenced area based on the higher number of Pteridophytes, the Rosaceae, Poaceae and Cyperaceae species. Based on the main characteristics of habitats within the Valley of Geysers, we grouped thermophytes within the following groups:

1. Mesophytes (both obligate and facultative thermophytes):

a. Mostly North Pacific species preferring rather acidic than neutral soils with high contents of Mn and $\mathrm{SOC}$, but low contents of $\mathrm{NO}_{3}^{-}, \mathrm{Al}, \mathrm{As}, \mathrm{Pb}$ (and to a lesser degree $\mathrm{Sr}$ ) and clay minerals suppressed by sulfates and high electrical conductivity (Pteridium aquilinum, Thalictrum minus, Angelica gmelinii, Artemisia opulenta, Aruncus dioicus, Cirsium kamtschaticum, Geranium erianthum, Maianthemum dilatatum);

b. Mostly boreal species preferring cool sandy soils predominantly in Erman's birch woods and herbaceous plant communities of Kamchatka (Aruncus dioicus, Maianthemum dilatatum, Pteridium aquilinum, Thalictrum minus);

c. Mostly boreal species occurring in Eurasia and North America without significant dependence on edaphic factors (Allium ochotense, Filipendula camtschatica, Galium boreale, Ophioglossum vulgatum, Sedum telephium, Viola selkirkii).

2. Obligate thermophytes that prefer soils:

a. Enriched in $\mathrm{NO}_{3}{ }^{-}$and hematite (Fimbristylis ochotensis);

b. With high contents of P, Si (quartz) and goethite, but low sulfate and electrical conductivity (Potentilla stolonifera);

c. Enriched in soil organic carbon (Dactylorhiza aristata);

d. With low contents of $\mathrm{As}$ and $\mathrm{Pb}$ (Epilobium glandulosum);

e. Without obvious requirements for edaphic factors (Moehringia lateriflora). 
3. Facultative thermophytes that prefer soils with:

a. A low carbonate alkalinity and low feldspar contents, but high electrical conductivity, sulfate and kaolinite contents (Agrostis geminata);

b. A high carbonate alkalinity (Picris hieracioides)

Therefore, this paper provides the basis for future transdisciplinary studies closing the gap between pedology and botany within the zone of influence of hydrothermal fields. Such studies are necessary to distinguish the influence of different environmental factors on vegetation, which in turn will help in understanding of the consequences of the global climate change.

Received: 17 October 2020; Accepted: 17 May 2021

Published online: 26 May 2021

\section{References}

1. Zavadskaya, A. V. et al. Atlas of the valley of the Geyzernaya river in the Kronotskiy Reserve. (Krasand, 2015). (in Russian).

2. Kiryukhin, A. Modeling and observations of geyser activity in relation to catastrophic landslides-mudflows (Kronotsky nature reserve, Kamchatka, Russia). J. Volcanol. Geoth. Res. 323, 129-147 (2016).

3. Rennert, T. \& Pfanz, H. Hypoxic and acidic-Soils on mofette fields. Geoderma https://doi.org/10.1016/j.geoderma.2016.06.019 (2016).

4. Nishar, A. \& Breen, D. Responses of vegetation to temperature gradients around geothermal features: A review on Wairakei-Tauhara geothermal field, Taupo, New Zealand. Geoinform. Geostat. Overview https://doi.org/10.4172/2327-4581.1000147 (2016).

5. Gennadiev, A. N., Geptner, A. R., Zhidkin, A. P., Chernyanskii, S. S. \& Pikovskii, Yu. I. Exothermic and endothermic soils of Iceland. Eurasian Soil Sci. https://doi.org/10.1134/S1064229307060014 (2007).

6. Menzel, P. et al. Comparative metagenomics of eight geographically remote terrestrial hot springs. Microb. Ecol. https://doi.org/ 10.1007/s00248-015-0576-9 (2015).

7. Smale, M. C., Wiser, S. K., Bergin, M. J. \& Fitzgerald, N. B. A classification of the geothermal vegetation of the Taupō Volcanic Zone, New Zealand. J. R. Soc. N. Z. https://doi.org/10.1080/03036758.2017.1322619 (2018).

8. Samkova, T. Y. Influence of the Hydrothermal Process on Vegetation. (Lomonosov Moscow State University, 2009). (in Russian).

9. Burns, B. Vegetation change along a geothermal stress gradient at the Te Kopia steamfield. J. R. Soc. N. Z. 27, 279-293 (1997).

10. Zhao, W., Romanek, C. S., Mills, G., Wiegel, J. \& Zhang, C. L. Geochemistry and microbiology of hot springs in Kamchatka Russia. Geol. J. China Univ. 11, 217-223 (2005).

11. Zavarzina, D. G. et al. Siderite-based anaerobic iron cycle driven by autotrophic thermophilic microbial consortium. Sci. Rep. https://doi.org/10.1038/s41598-020-78605-7 (2020).

12. Wilkins, L. G. E., Ettinger, C. L., Jospin, G. \& Eisen, J. A. Metagenome-assembled genomes provide new insight into the microbial diversity of two thermal pools in Kamchatka, Russia. Sci. Rep. https://doi.org/10.1038/s41598-019-39576-6 (2019).

13. Rozanov, A. S. et al. Molecular analysis of the benthos microbial community in Zavarzin thermal spring (Uzon Caldera, Kamchatka, Russia). BMC Genom. https://doi.org/10.1186/1471-2164-15-S12-S12 (2014).

14. Kochetkova, T. V. et al. Thermogladius calderae gen. nov., sp. Nov., an anaerobic, hyperthermophilic crenarchaeote from a Kamchatka hot spring. Int. J. Syst. Evol. Microbiol. https://doi.org/10.1099/ijsem.0.000916 (2016).

15. Hewitt, A. E. New Zealand soil classification. (Manaaki Whenua Press, 2010).

16. Sedov, S., Stoops, G. \& Shoba, S. Regoliths and Soils on Volcanic Ash. in Interpretation of Micromorphological Features of Soils and Regoliths (2010). https://doi.org/10.1016/B978-0-444-53156-8.00013-1.

17. Tangari, A. C., Scarciglia, F., Piluso, E., Marinangeli, L. \& Pompilio, L. Role of weathering of pillow basalt, pyroclastic input and geomorphic processes on the genesis of the Monte Cerviero upland soils (Calabria, Italy). CATENA https://doi.org/10.1016/j. catena.2018.07.015 (2018).

18. Gol'dfarb, I. L. Influence of a hydrothermal process on soil formation (on the example of Kamchatka). (Lomonosov Moscow State University, 2005). (in Russian).

19. Romanis, T. \& Lebedeva, M. Microfeatures of cryogenesis in Pym-Va-Shor hydrothermal fields soils, Nenets autonomous area, Russia. in Cryosols in perspective: a view from the permafrost heartland. Proceedings of the VII International Conference on Cryopedology 122-123 (P.I. Melnikov Permafrost Institute, SB RAS, 2017).

20. Khitrov, N. B. et al. Gas-hydrothermal turbation of soils as a factor of microhighs forming. Eurasian Soil Sci. https://doi.org/10. 1134/S1064229320020064 (2020).

21. Khitrov, N. B. et al. Morphology of Soils in the Impact Zone of Kuchiger Hot Springs, the Barguzin Depression. Eurasian Soil Sci. https://doi.org/10.1134/S106422931912007X (2019).

22. Kaasalainen, H. \& Stefánsson, A. The chemistry of trace elements in surface geothermal waters and steam, Iceland. Chem. Geol. 330-331, 60-85 (2012).

23. Gol'dfarb, I. L. Effect of hydrothermal activity on the conditions of pedogenesis and soil morphology (by the example of Kamchatka). Eurasian Soil Sci. 29, 1319-1324 (1996).

24. Kostyuk, D. N. \& Gennadiev, A. N. Soils and the soil cover of the Valley of Geysers. Eurasian Soil Sci. 47, 529-539 (2014).

25. Geptner, A. R. et al. Hydrothermally altered hyaloclastites at the Earth's surface in the rift zone of Iceland: Problem of the biochemogenic accumulation of trace elements. Lithol. Min. Resour. https://doi.org/10.1134/S0024490207050045 (2007).

26. Naboko, S. I. The metal behaviour by interaction of thermal water with rock in the bowels of Kamchatka hydrothermal systems. in Proceedings of 2nd International Symposium on Water-Rock Interaction 19-29 (1977).

27. Ladygin, V. M., Frolova, Y. V. \& Rychagov, S. N. The alteration of effusive rocks due to acidic leaching by shallow thermal waters: The Baranskii geothermal system, Iturup Island. J. Volcanol. Seismolog. https://doi.org/10.1134/S0742046314010035 (2014).

28. Rychagov, S. N., Sokolov, V. N. \& Chernov, M. S. Hydrothermal clays of the geothermal fields of South Kamchatka: A new approach and study results. Geochem. Int. https://doi.org/10.1134/S0016702912020073 (2012).

29. Rychagov, S. N. et al. Cation migration in hydrothermal clays: The problem of mineralization criteria in gas-hydrothermal fluids of hydrothermal fields in Southern Kamchatka. J. Volcanol. Seismolog. https://doi.org/10.1134/S0742046312040069 (2012).

30. Ivanov, A., Shoba, S. \& Krasilnikov, P. A pedogeographical view of volcanic soils under cold humid conditions: The Commander Islands. Geoderma https://doi.org/10.1016/j.geoderma.2014.06.031 (2014).

31. Mileti, F. A., Vingiani, S., Manna, P., Langella, G. \& Terribile, F. An integrated approach to studying the genesis of andic soils in Italian non-volcanic mountain ecosystems. CATENA https://doi.org/10.1016/j.catena.2017.07.022 (2017).

32. Gvozdeva, I. P., Frolova, J. V. \& Zerkal, O. V. Slope processes hazards in geothermal areas: A case study of the Geysers Valley, Kamchatka. in Proceedings World Geothermal Congress 2015 (2015). 
33. Shoji, S., Nanzyo, M. \& Dahlgren, R. A. Volcanic ash soils: genesis, properties and utilization. Volcanic ash soils: genesis, properties and utilization (1993).

34. Duchaufour, P. Pedology. (Springer Netherlands, 1982).https://doi.org/10.1007/978-94-011-6003-2.

35. Takahashi, T. \& Dahlgren, R. A. Nature, properties and function of aluminum-humus complexes in volcanic soils. Geoderma 263, 110-121 (2016).

36. Kılıç, K., Yalçın, H., Durak, A. \& Doğan, H. M. Andisols of Turkey: An example from the Cappadocian Volcanic Province. Geoderma https://doi.org/10.1016/j.geoderma.2017.10.019 (2018).

37. Díaz, F. J., O'Geen, A. T., Rasmussen, C. \& Dahlgren, R. A. Pedogenesis along a thermal gradient in a geothermal region of the southern Cascades, California. Geoderma https://doi.org/10.1016/j.geoderma.2009.05.017 (2010).

38. Harvey, C. C. \& Browne, P. R. L. Mixed-layer clay geothermometry in the Wairakei geothermal field, New Zealand. Clays Clay Miner. https://doi.org/10.1346/CCMN.1991.0390607 (1991).

39. Sakharov, B. A., Drits, V. A., McCarty, D. K. \& Walker, G. M. Modeling powder x-ray diffraction patterns of the clay minerals society kaolinite standards: KGA-1, KGA-1b, and KGa-2. Clays Clay Miner. https://doi.org/10.1346/CCMN.2016.0640307 (2016).

40. Stoops, G. J. Guidelines for Analysis and Description of Soil and Regolith Thin Sections. (Soil Science Society of America, 2003).

41. Karpachevsky, L. O., Il'ina, L. S., Milonov, P. A. \& Startseva, N. A. On the formation of clay iron-containing parent materials on volcanic ash affected by thermalwaters in the territory of Kronotskiy reserve. Pochvovedenie 6, 17-24 (1989).

42. Migdisov, A. A. \& Bychkov, A. Y. The behaviour of metals and sulphur during the formation of hydrothermal mercury-antimonyarsenic mineralization, Uzon caldera, Kamchatka, Russia. J. Volcanol. Geoth. Res. 84, 153-171 (1998).

43. Frolova, J. V., Ladygin, V. M. \& Rychagov, S. N. Petrophysical alteration of volcanic rocks in hydrothermal systems of the KurilKamchatka Island Arc. in Proceedings World Geothermal Congress 1-7 (2010).

44. Eroshchev-Shak, V. A. Hydrothermal subsurface lithogenesis of the Kuril-Kamchatka region. (Nauka, 1992). (in Russian).

45. Legkodymov, A. A. et al. Optical and X-ray imaging analysis of chemical elements associated with microbial communities. Bull. Russ. Acad. Sci. Phys. https://doi.org/10.3103/S106287381309027X (2013).

46. Rychagov, S. N., Sokolov, V. N. \& Chernov, M. S. Hydrothermal clays as a highly dynamical colloid-disperse mineralogicalgeochemical system. Dokl. Earth Sci. https://doi.org/10.1134/S1028334X10120275 (2010).

47. Kiryukhin, A. V., Shadrina, S. V. \& Puzankov, M. Y. Modeling the thermohydrogeochemical conditions for the generation of productive reservoirs in volcanogenic rocks. J. Volcanol. Seismolog. https://doi.org/10.1134/S0742046313020036 (2013).

48. Kiryukhin, A. V., Rychkova, T. V. \& Dubrovskaya, I. K. Formation of the hydrothermal system in Geysers Valley (Kronotsky Nature Reserve, Kamchatka) and triggers of the Giant Landslide. Appl. Geochem. https://doi.org/10.1016/j.apgeochem.2012.02. 011 (2012).

49. Kuzmina, EYu., Potemkin, A. D. \& Neshataeva, VYu. Bryophytes (Bryophyta, Marchantiophyta) of thermal habitats of the Lagoon Tintikun, Northern Koryakia, Kamchatka Territory. Novosti Sistematiki Nizshikh Rastenii https://doi.org/10.31111/nsnr/2020. 54.1.189 (2020).

50. Neshataeva, VYu., Pesterov, A. O. \& Korablev, A. P. Cenotic Diversity of vegetation in thermal habitats of the Kronotsky reserve. Trudy Kronotskogo Gosudarstvennogo Prirodnogo Biosfernogo Zapovednika 4, 31-40 (2015).

51. Convey, P., Smith Lewis, R. I., Hodgson, D. S. \& Peat, H. J. The flora of the South Sandwich Islands, with particular reference to the influence of geothermal heating. J. Biogeogr. 27, 1279-1295 (2000).

52. Convey, P. \& Smith Lewis, R. I. Geothermal bryophyte habitats in the South Sandwich Islands, maritime Antarctic. J. Biogeogr. 17, 529-538 (2006).

53. Elmarsdóttir, Á., Vilmundardóttir, O. K. \& Magnússon, S. H. Vegetation of high-temperature Geothermal Areas in Iceland. in Proceedings of the World Geothermal Congress 1-11 (2015).

54. Glime, J. M. \& Hong, W. S. Relationships of geothermal bryophyte communities to soil characteristics at Thermal Meadow, Hotsprings Island, Queen Charlotte Islands, Canada. J. Bryol. 19, 435-448 (1997).

55. Rajput, V. et al. Phylogenetic analysis of hyperaccumulator plant species for heavy metals and polycyclic aromatic hydrocarbons. Environ. Geochem. Health https://doi.org/10.1007/s10653-020-00527-0 (2020).

56. Channing, A. \& Edwards, D. Wetland megabias: Ecological and ecophysiological filtering dominates the fossil record of hot spring floras. Palaeontology https://doi.org/10.1111/pala.12043 (2013).

57. Kim, Y. B. et al. Molecular identification of Allium ochotense and Allium microdictyon using multiplex-PCR based on single nucleotide polymorphisms. Hortic. Environ. Biotechnol. https://doi.org/10.1007/s13580-018-0069-0 (2018).

58. Barrett, T. J. \& Joseph, E. P. Extreme alteration in an acid-sulphate geothermal field: Sulphur Springs, Saint Lucia. Chem. Geol. https://doi.org/10.1016/j.chemgeo.2018.09.028 (2018).

59. Nishar, A. Undertanding warming effects on vegetation through geothermal hotspots: A case study of the Wairakei-Tauhara geothermal field, Taupo, New Zeland. (Institute for Applied Ecology New Zeland, 2017).

60. Burns, B. \& Leathwick, J. Geothermal vegetation dynamics by Part 1: Map of Geothermal Vegetation of the Te Kopia Scenic Reserve. Part 2: Plant species organisation along major environmental. Science for Conservation 18. gradients. (Department of Conservation, 1995).

61. Nishar, A. et al. Temperature effects on biomass and regeneration of vegetation in a geothermal area. Front. Plant Sci. 8, (2017).

62. van Manen, S. M. \& Reeves, R. An assessment of changes in kunzea ericoides var microflora and other hydrothermal vegetation at the Wairakei-Tauhara geothermal field, New Zealand. Environ. Manag. https://doi.org/10.1007/s00267-012-9899-1 (2012).

63. Glime, J. M. \& Iwatsuki, Z. Geothermal communities of Ponponyama, Hokkaido, Japan. J. Hattori Bot. Lab. 75, 133-147 (1994).

64. Kikawada, Y., Ono, T., Ogawa, K., Fukai, M. \& Oi, T. Chemical geothermometry studies on a geothermal system in Manza hot springs near Kusatsu-Shirane Volcano, Japan. Procedia Earth Planet. Sci. https://doi.org/10.1016/j.proeps.2016.12.048 (2017).

65. Kuznetsova, E. \& Motenko, R. Weathering of volcanic ash in the cryogenic zone of Kamchatka, eastern Russia. Clay Miner. https://doi.org/10.1180/claymin.2014.049.2.04 (2014).

66. Denelle, P., Violle, C. \& Munoz, F. Generalist plants are more competitive and more functionally similar to each other than specialist plants: insights from network analyses. J. Biogeogr. https://doi.org/10.1111/jbi.13848 (2020).

67. Lloret, F. et al. Species attributes and invasion success by alien plants on Mediterranean islands. J. Ecol. https://doi.org/10.1111/j. 1365-2745.2005.00979.x (2005).

68. Linder, H. P., Lehmann, C. E. R., Archibald, S., Osborne, C. P. \& Richardson, D. M. Global grass (Poaceae) success underpinned by traits facilitating colonization, persistence and habitat transformation. Biol. Rev. https://doi.org/10.1111/brv.12388 (2018).

69. Larson, D. W., Porembski, S. \& Barthlott, W. Inselberg biodiversityinselbergs: Biotic diversity of isolated rock outcrops in tropical and temperate regions. Ecology https://doi.org/10.2307/2680240 (2001).

70. Popp, M. Genotypic differences in the mineral metabolism of plants adapted to extreme habitats. Genet. Asp. Plant Nutr. https:// doi.org/10.1007/978-94-009-6836-3_22(1983).

71. Yakubov, V. V. \& Chernyagina, O. A. Catalog of Flora of Kamchatka (Vasculare Plants). (Kamchatsky Petchatnij Dvor, 2003). (in Russian).

72. Zavadskaya, A. V., Lebedeva, E. V., Sugrobov, V. M. \& Chizhova, V. P. Valley of Geysers (Kamchatka)—One of the Largest Geyser Fields in the World. in Landforms and Landscapes of Russia In press (Springer, 2021).

73. Bryan, T. S. Heart lake Geyser Basin. in The Geysers of Yellowstone, Fifth Edition (2018). https://doi.org/10.2307/j.ctv233kv0.18.

74. Leonov, A. V. History of the cartography and toponymy of the Valley of Geysers (Kronotsky Reserve, Kamchatka Peninsula, Russia): From field drawings to 3D documents. Cartograph. J. https://doi.org/10.1080/00087041.2017.1414020 (2018). 
75. Leonov, A. V. Catalogue of geysers of the Kronotsky reserve. The Valley of Geysers and the Uzon Volcano Caldera: History and Modernityness. (Restart Ltd., 2017).

76. Bryan, S. T., Rinehart, J. S. \& Hobart, J. The Geysers of "The Valley of Geysers." (B\&J Printing, 1991).

77. Kiryukhin, A. V. \& Rychkova, T. V. Functioning of natural and natural-engineering systems formation conditions and natural state of the hydrothermal system in the Valley of Geysers (Kronotsky Nature Reserve, Kamchatka). Water Resour. https://doi. org/10.1134/S0097807812070056 (2012).

78. Given, D. R. Vegetation on heated soils at Karapiti, central North Island, New Zealand, and its relation to ground. NZ J. Bot. 18, $1-13(1980)$.

79. Kugaenko, Y. A., Saltykov, V. A., Gorbatikov, A. V. \& Stepanova, M. Y. The model of the Uzon-Geizernaya volcano-tectonic depression and Kikhpinych volcano, Kamchatka, from the joint analysis of microseismic sounding data and local geodynamic activity. Izvestiya Phys. olid Earth https://doi.org/10.1134/S106935131503009X (2015).

80. Bindeman, I. N. et al. Large-volume silicic volcanism in Kamchatka: Ar-Ar and U-Pb ages, isotopic, and geochemical characteristics of major pre-Holocene caldera-forming eruptions. J. Volcanol. Geoth. Res. https://doi.org/10.1016/j.jvolgeores.2009.10. 009 (2010).

81. Rassokhina, L. I. \& Chernyagina, O. A. Phytocenoses of the Valley of Geysers Thermal fields. in Structure and dynamics of vegetation and soils in the reserves of the RSFSR 51-62 (TsNIIL, 1982). (in Russian).

82. Samkova, T. Y., Rylova, S. A. \& Klyapitsky, E. S. Spatial heterogeneity of the thermal field and its reflection in structure of the vegetation cover of the southeast part of the Bolshe-Banny high-temperature deposit (Southern Kamchatka). Bull. KRAUNTs Earth Sci. 31, 18-27 (2016).

83. Trass, Kh. Kh. On the vegetation of the vicinities of hot springs and geysers of the Valley of the Geysers in Kamchatka Peninsula. in Investigation of the nature of the Far East 112-146 (Academy of Sciences of the Estonian SSR, 1963). (in Russian).

84. Zavadskaya, A. V., Yablokov, V. M. \& Prozorova, M. V. GIS-mapping of thermal fields by the structure of vegetation cover (case study in the Valley of the Geysers). Bull. Kronotsky State Federal Biosph. Reserve 2, 103-119 (2012).

85. Waltham, T. A guide to the volcanoes of southern Kamchatka, Russia. Proc. Geol. Assoc. https://doi.org/10.1016/S0016-7878(01) 80051-1 (2001).

86. Belousov, V. I., Grib, E. N. \& Leonov, V. L. The geological setting of the hydrothermal systems in the Geysers Valley and Uzon Caldera. Volcanol. Seismol. (1984).

87. Peel, M. C., Finlayson, B. L. \& McMahon, T. A. Updated world map of the Köppen-Geiger climate classification. Hydrol. Earth Syst. Sci. https://doi.org/10.5194/hess-11-1633-2007 (2007).

88. Litvinenko, Y. S. \& Zakharikhina, L. V. Zoning and geochemical characterization of volcanic soils on Kamchatka. Geochem. Int. https://doi.org/10.1134/S0016702909050036 (2009).

89. Kiryukhin, A. V., Rychkova, T. V. \& Dubinina, E. O. An analysis of hydrogeological behavior in the Geyser Valley, Kronotskii nature reserve, Kamchatka after the disaster of June 3, 2007. J. Volcanol. Seismolog. https://doi.org/10.1134/S07420463150100 30 (2015).

90. Zakharikhina, L. V. \& Litvinenko, Yu. S. Specific features of the morphology of volcanic soils in the altitudinal zones of Kamchatka. Eurasian Soil Sci. 46, 611-621 (2013).

91. Marechek, M. S., Alyabina, I. O. \& Shoba, S. A. The soil cover of Central Kamchatka (GIS model). Eurasian Soil Sci. 42, 1193-1203 (2009).

92. Zakharikhina, L. V. \& Litvinenko, Yu. S. Chemical composition of soils in the areas of volcanic ashfalls around active volcanoes in Kamchatka. Eurasian Soil Sci. 49, 305-314 (2016).

93. Zakharikhina, L. V. Soil formation on acid and basic volcanic ashes of different ages in Kamchatka. Eurasian Soil Sci. https:// doi.org/10.1134/S1064229306090031 (2006).

94. Dobretsov, N. L. et al. Geological, hydrogeochemical, and microbiological characteristics of the Oil site of the Uzon caldera (Kamchatka). Russ. Geol. Geophys. https://doi.org/10.1016/j.rgg.2015.01.003 (2015).

95. Zavadskaya, A. V. \& Golubeva, E. I. Natural complexes of hydrothermal systems of Kamchatka as objects for recreation and tourism. Geogr. Nat. Resour. 34, 339-344 (2013).

96. Zenova, G. M., Kurapova, A. I., Lysenko, A. M. \& Zvyagintsev, D. G. The structural-functional organization of thermotolerant complexes of actinomycetes in desert and volcanic soils. Eurasian Soil Sci. https://doi.org/10.1134/S1064229309050081 (2009).

97. Merkel, A. Y. et al. Microbial diversity and autotrophic activity in Kamchatka hot springs. Extremophiles https://doi.org/10.1007/ s00792-016-0903-1 (2017)

98. Merrett, M. F. \& Clarkson, B. R. Definition, description and illustrations of geothermally influenced terrestrial and emergent wetland vegetation. Contract Report: LC9900/022 Contract Report. (1999).

99. Chiarucci, A., Calderisi, M., Casini, F. \& Bonini, I. Vegetation at the limits for vegetation: Vascular plants, bryophytes and lichens in a geothermal field. Folia Geobot. 43, 19-33 (2008).

100. Muukkonen, P. Conservation aspects of geothermal vegetation. Pac. Conserv. Biol. 12, 255-258 (2006).

101. Smale, M. C. \& Wiser, S. K. A Classification of the geothermal vegetation of the Taupo Volcanic Zone, New Zealand. in Proceedings World Geothermal Congress 1-11 (2015).

102. Stout, R. G., Summers, M. L., Kerstetter, T. \& McDermott, T. R. Heat- and acid-tolerance of a grass commonly found in geothermal areas within Yellowstone National Park. Plant Sci. https://doi.org/10.1016/S0168-9452(97)00205-7 (1997).

103. Taylor, S. R. \& McLennan, S. M. The geochemical evolution of the continental crust. Rev. Geophys. 32, 241-265 (1995).

104. Boothroyd, I. K. G. Ecological characteristics and management of geothermal systems of the Taupo Volcanic Zone, New Zealand. Geothermics https://doi.org/10.1016/j.geothermics.2008.12.010 (2009).

105. Robinson, S. I., McLaughlin, Ó. B., Marteinsdóttir, B. \& O'Gorman, E. J. Soil temperature effects on the structure and diversity of plant and invertebrate communities in a natural warming experiment. J. Anim. Ecol. https://doi.org/10.1111/1365-2656.12798 (2018).

106. Sheppard, J. S. The influence of geothermal temperature gradients upon vegetation patterns in Yellowstone National Park. (Colorado State University, 1971).

107. Stout, R. G. \& Al-Niemi, T. S. Heat-tolerant flowering plants of active geothermal areas in Yellowstone National Park. Ann. Bot. https://doi.org/10.1093/aob/mcf174 (2002).

108. Romanis, T. V. Soil formation in hydrothermal zones of the Subarctic (on the example of the Pym-Va-Shor urochische tract of the Bolshezemelskaya tundra). (V.V. Dokuchaev Soil Science Institute, 2021). (in Russian).

109. Neshataeva, V. Y. Vegetation cover of Kamchatka. (KMK, 2009). (in Russian).

110. Rassokhina, L. I. Flora and Vegetation. in Vegetation and Animals of the Valley of the Geysers 32-71 (Kapchatsky Printing Yard, 2002). (in Russian).

111. Rassokhina, L. I. \& Ovcharenko, L. V. No Title. Pap. Kamchatka’s Branch Pac. Inst. Geogr. FEB RAS 5, 394-403 (2004).

112. Beadel, S. et al. Sustainable management of geothermal vegetation in the Waikato Region, New Zealand, including application of ecological indicators and new monitoring technology trials. Geothermics https://doi.org/10.1016/j.geothermics.2017.11.001 (2018).

113. Given, D. R. Geothermal Vegetation-An assessment of botanical values of selected geothermal sites in the Taupo Volcanic Zone. (1995). 
114. Karlsen, S. R., Elvebakk, A. \& Johansen, B. A vegetation-based method to map climatic variation in the arctic-boreal transition area of Finnmark, North-Easternmost Norway. J. Biogeogr. 32, 1161-1186 (2005).

115. Yablokov, V. \& Zavadskaya, A. Geoinformation modeling of hydrothermal systems temperature fields (on the example of the river Geysernaya valley. Geod. Cartogr. 3, 24-31 (2013).

116. Bromley, C. J. \& Hochstein, M. P. Heat Discharge of Steaming Ground at Karapiti (Wairakei), New Zealand. World Geothermal Congress (2005).

117. Munsell, A. H. Munsell soil color charts. Munsell Color Co. https://doi.org/10.1021/ja1019063 (2000).

118. Barham, P. et al. Guidelines for soil description Fourth edition (Food and Agriculture Organization of the United Nations, 2006). https://doi.org/10.2165/00115677-199701040-00003.

119. FAO. World reference base for soil resources 2014 International soil classification system. World Soil Resources Reports No. 106 (FAO, 2015).

120. Vaicys, M. \& Mazvila, J. Comparative studies and assessment of the particle-size distribution in soils of Lithuania by the Kachinskii and FAO methods. Eurasian Soil Sci. https://doi.org/10.1134/S1064229309030065 (2009).

121. Shein, E. V. The particle-size distribution in soils: Problems of the methods of study, interpretation of the results, and classification. Eurasian Soil Sci. https://doi.org/10.1134/S1064229309030053 (2009).

122. Harris, W. \& White, N. G. X-ray diffraction techniques for soil mineral identification. in Methods of soil analysis (eds. Ulery, A. L. \& Drees, R.) 81-115 (2008). https://doi.org/10.2136/sssabookser5.5.c4.

123. Moore, D. M. \& Reynolds, R. C. Jr. X-Ray Diffraction and the Identification and Analysis of Clay Minerals (Oxford University Press, 1997). :https://doi.org/10.1017/S0016756898501501.

124. Drits, V. A. \& Kossovskaya, A. G. Clay Minerals: Smectites and Mixed-Layer Minerals. (Nauka, 1990). (in Russian).

125. Bish, D. L. \& Post, J. E. Quantitative mineralogical analysis using the Rietveld full-pattern fitting method. Am. Mineral. (1993).

126. Doebelin, N. \& Kleeberg, R. Profex: A graphical user interface for the Rietveld refinement program BGMN. J. Appl. Crystallogr. https://doi.org/10.1107/S1600576715014685 (2015).

127. Blakemore, L. C., Searle, P. L. \& Daly, B. K. Method for chemical analysis of soils. N. Z. Soil Bureau Sci. Rep. (1987).

128. Rychagov, S. N., Sergeeva, A. V. \& Chernov, M. S. Specific mineral associations of hydrothermal shale (South Kamchatka). Dokl. Earth Sci. https://doi.org/10.1134/S1028334X17110071 (2017).

129. Frolova, Y. V.et al. Variation in the physical and mechanical properties of rocks: The North Paramushir hydrothermal magmatic system, Kuril Islands. J. Volcanol. Seismolog. https://doi.org/10.1134/S0742046316030039 (2016).

130. Belogub, E. V., Simonov, A. N. \& Simonov, V. A. Features of the mineral composition and structure of clays from hydrotherms of the Valley of Geysers (Kamchatka). in Metallogeny of ancient and modern oceans-2007. Hydrothermal and hypergene orebearing systems 68-72 (2007). (in Russian).

131. Sergeeva, A. V., Denisov, D. K. \& Nazarova, M. A. Clay mineral assemblages in recent thermal anomalies of Southern Kamchatka. Russ. Geol. Geophys. https://doi.org/10.15372/RGG2019090 (2019).

132. Kiryukhin, A. V., Rychkova, T. V. \& Sergeeva, A. V. Simulating the conditions of generation for permeable geyser channels in areas of acid volcanism. J. Volcanol. Seismolog. https://doi.org/10.1134/S0742046320020037 (2020).

133. Frolova, J. V. et al. The influence of hydrothermal argillization on the physical and mechanical properties of tuffaceous rocks: A case study from the Upper Pauzhetsky thermal field, Kamchatka. Bull. Eng. Geol. Environ. https://doi.org/10.1007/s10064-02002007-2 (2020).

134. Lee, R. G., Dilles, J. H., John, D. A. \& Abela, T. L. The mineralogy and origin of hydrothermally altered Quaternary volcanic rocks on the south flank of Lassen volcano, California: Interim report for USGS Mineral Resource External Research. (2005).

135. Henneberger, R. C. \& Browne, P. R. L. Hydrothermal alteration and evolution of the Ohakuri hydrothermal system, Taupo volcanic zone, New Zealand. J. Volcanol. Geoth. Res. https://doi.org/10.1016/0377-0273(88)90034-0 (1988).

136. R Core Team (2020). R: A language and environment for statistical computing. R: A language and environment for statistical computing. R Foundation for Statistical Computing, Vienna, Austria (2020).

137. Jayawardena, U. D. S. \& Izawa, E. A new chemical index of weathering for metamorphic silicate rocks in tropical regions: A study from Sri Lanka. Eng. Geol. https://doi.org/10.1016/0013-7952(94)90011-6 (1994).

138. Birkeland, P. Soils and Geomorphology. (Oxford University Press, 1999).

139. Yakubov, V. V. Vascular plants of the Kronotsky Biosphere Reserve (Kamchatka). (1997). (in Russian).

140. Webb, C. O., Ackerly, D. D., McPeek, M. A. \& Donoghue, M. J. Phylogenies and community ecology. Annu. Rev. Ecol. Syst. https:// doi.org/10.1146/annurev.ecolsys.33.010802.150448 (2002).

141. Qian, H. \& Jin, Y. An updated megaphylogeny of plants, a tool for generating plant phylogenies and an analysis of phylogenetic community structure. J. Plant Ecol. https://doi.org/10.1093/jpe/rtv047 (2016).

142. Webb, C. O. \& Donoghue, M. J. Phylomatic: Tree assembly for applied phylogenetics. Mol. Ecol. Notes https://doi.org/10.1111/j. 1471-8286.2004.00829.x (2005).

143. Harrell, F. E. Hmisc: Harrell miscellaneous. R package version 4.4-0 (2020).

144. Frolova, Y. V., Surovtseva, K. I., Chernov, M. S. \& Rychagov, S. N. Changes in andesites in the acid leaching zone of the South Kambal Far Thermal Field (Kamchatka). in XXI Annual Scientific Conference dedicated to Volcanologist Day "Volcanism and related processes" (eds. Gordeev, E. I. \& Kozhurin, A. I.) 218-221 (Institute of Volcanology and Seismology, 2018). (in Russian).

145. Verma, S. P., Pandarinath, K., Bhutani, R. \& Dash, J. K. Mineralogical, chemical, and Sr-Nd isotopic effects of hydrothermal alteration of near-surface rhyolite in the Los Azufres geothermal field, Mexico. Lithos https://doi.org/10.1016/j.lithos.2018.10. 021 (2018).

\section{Acknowledgements}

Analyses of mineralogical and chemical composition of soils was conducted at the Lomonosov Moscow State University (MSU) and field work was supported by the Russian Foundation for Basic Research (Project No. 15-04-03818). Mineralogical studies were partially performed using equipment acquired with the funding of the MSU Development Program (X-ray diffractometer Ultima-IV, Rigaku and Scanning Electron Microscope LEO 1450VP, Carl Zeiss) and project AAAA-A16-116033010115-6 (SEM). The XRD data were interpreted within the framework of the state assignment of the Institute of Geology of Ore Deposits, Petrography, Mineralogy and Geochemistry of the Russian Academy of Sciences (IGEM RAS). HP-IC and AES analyses and data interpretation were supported by the Russian Science Foundation (Project No. 17-77-20072). We are thankful to M.A. Lebedev for preparing thin sections, S.V. Zakusin (IGEM RAS/MSU) and S.A Garanina (MSU) for conducting XRD analysis, T.G. Sukhova and E.A. Shakhpenderyan (MSU) for preparing ammonium oxalate and ammonium acetate extracts, L.V. Dobrydneva (MSU) for HP-IC analysis of water extracts (these works were supported by MSU projects "Anthropogenic geochemical transformation of the components of landscapes" and "Future Planet and Global Environmental Change»"), V.K. Karandashev (the Institute of Microelectronics Technology Problems and High Purity Materials of the Russian Academy of Sciences (IMT RAS)) for AES analysis of oxalate and an ammonium acetate buffer extracts and K. Moskovtsev, E. Saltykova and anonymous Reviewer \#3 
for their valuable comments. Authors are grateful to I. Spiridonova and M. Hayes for help with the manuscript preparation.

\title{
Author contributions
}

I.S.-Conceptualization, Methodology (field and laboratory works, soil chemistry, statistics), Investigation (soil chemistry, mineralogy, statistics, geobotany), Writing (original draft, review and editing, artwork: Figs. 1-5, S1-S7, Tables 1, 2, S1-S12, S14-S24), Project co-administration. G.K.-Conceptualization, Methodology (field work, evolutionary analysis, statistics), Investigation (geobotany, plant phylogeny), Writing (geobotany, plant phylogeny: original draft, review and editing, artwork: Figs. 4b, c, S3, S5, Tables S3-S13, S15-S19). M.L.-Conceptualization, Methodology (micromorphology), Investigation (micromorphology and mineralogy), Writing (micromorphology: original draft, review and editing, Fig. 2). V.K.-Conceptualization, Methodology (mineralogy, SEM), Investigation (mineralogy, SEM), Writing (review and editing: mineralogy, SEM, artwork: Figs. 3, 5, Table S23). M.C.-Methodology (mineralogy, SEM), Investigation (SEM), Writing (original draft, review, editing, art work: mineralogy, SEM, Figs. 2, 5). O.D.-Investigation (mineralogy), Writing (mineralogy: review, Fig. 3). M.K.-Investigation (field and laboratory works). V.S.-Conceptualization (mineralogy, SEM), Methodology (mineralogy, SEM). A.Z.-Conceptualization, Methodology (field work, geobotany), Investigation (geobotany), Writing (geobotany: original draft, review and editing, artwork: Figs. 1, S2-S5, Tables 1, S1, S2, S14, S24), Field work and Project administration, Funding acquisition.

\section{Competing interests}

The authors declare no competing interests.

\section{Additional information}

Supplementary Information The online version contains supplementary material available at https://doi.org/ 10.1038/s41598-021-90712-7.

Correspondence and requests for materials should be addressed to I.N.S.

Reprints and permissions information is available at www.nature.com/reprints.

Publisher's note Springer Nature remains neutral with regard to jurisdictional claims in published maps and institutional affiliations.

\begin{abstract}
(c) (i) Open Access This article is licensed under a Creative Commons Attribution 4.0 International License, which permits use, sharing, adaptation, distribution and reproduction in any medium or format, as long as you give appropriate credit to the original author(s) and the source, provide a link to the Creative Commons licence, and indicate if changes were made. The images or other third party material in this article are included in the article's Creative Commons licence, unless indicated otherwise in a credit line to the material. If material is not included in the article's Creative Commons licence and your intended use is not permitted by statutory regulation or exceeds the permitted use, you will need to obtain permission directly from the copyright holder. To view a copy of this licence, visit http://creativecommons.org/licenses/by/4.0/.
\end{abstract}

(C) The Author(s) 2021 